\title{
Stratigraphy and \\ Tertiary Development of the Continental Margin East of Florida
}

GEOLOGICALSURVEY PROFESSIONALPAPER 581-F

Prepared in cooperation with the Woods Hole

Oceanographic Institution and the Joint

Oceanographic Institutions' Deep Earth

Sampling Program

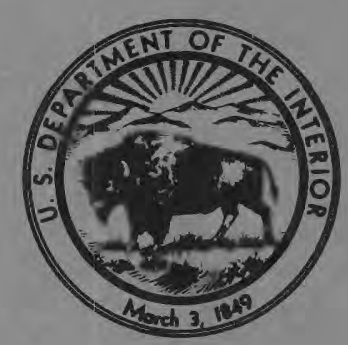


$x^{2}+x^{2}-x^{2}$

$x=$

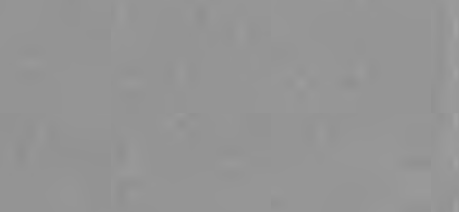

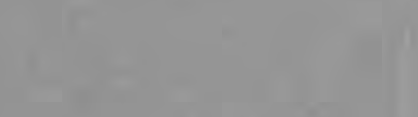

$12+2+2=2$

tons

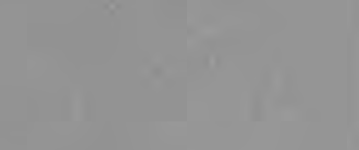

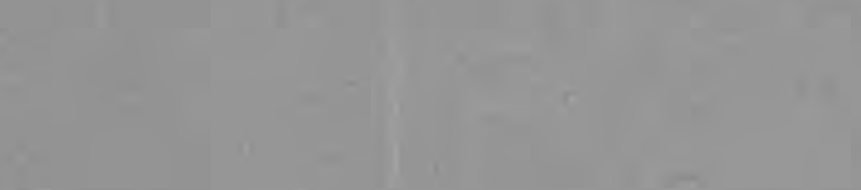

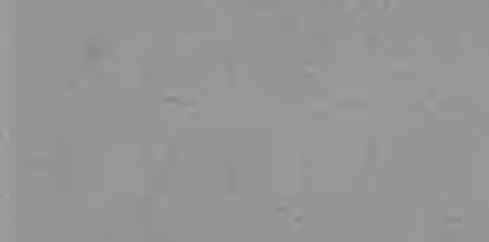

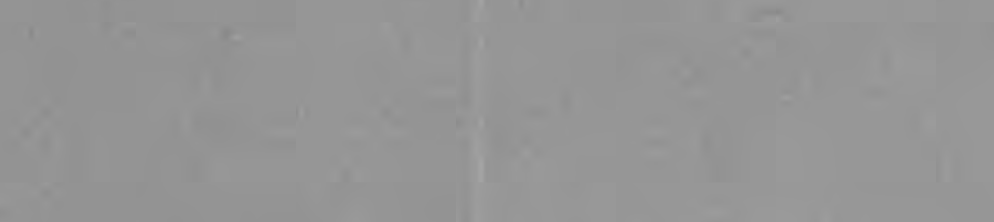

(1)

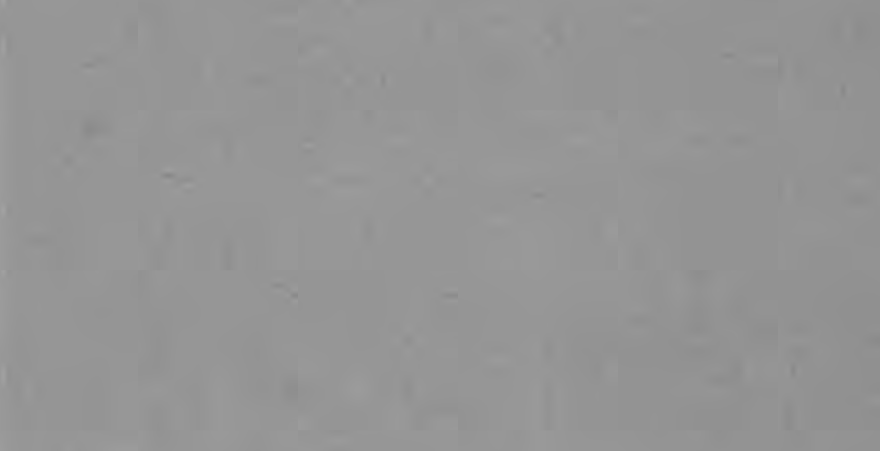

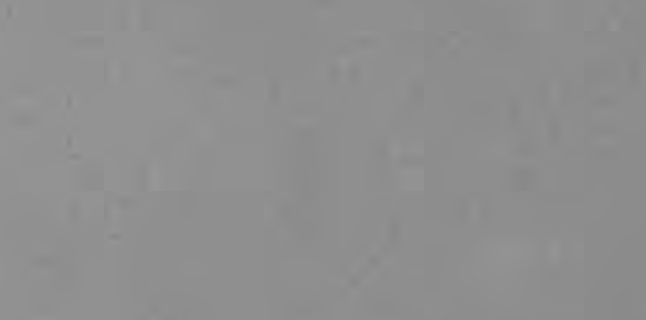

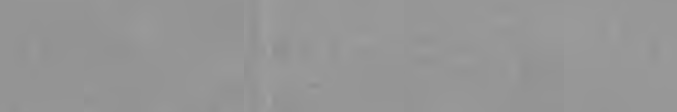

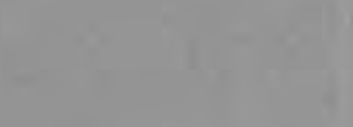

$=2 x-41$

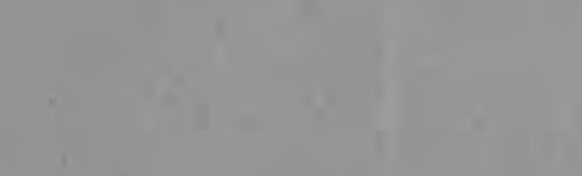

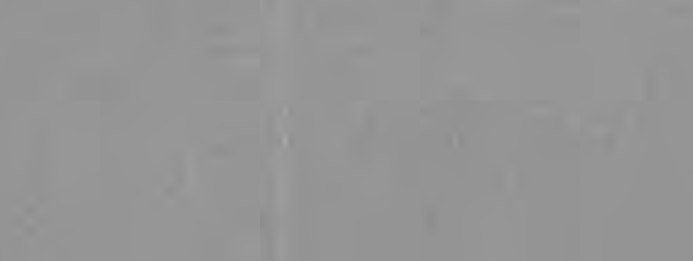

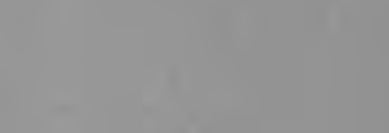

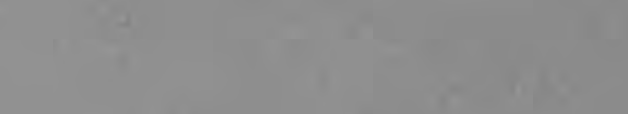

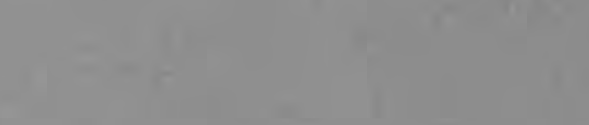

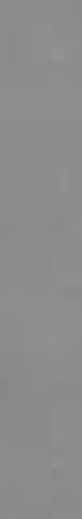


Stratigraphy and

Tertiary Development of the

Continental Margin East of

Florida

By JOHN SCHLEE

DRILLING ON THE CONTINENTAL MARGIN OFF FLORIDA

G E O O G I A L S UR VEY PROFESSIONAL PAPER $581-$ F

Prepared in cooperation with the Woods Hole

Oceanographic Institution and the Joint

Oceanographic Institutions' Deep Earth

Sampling Program

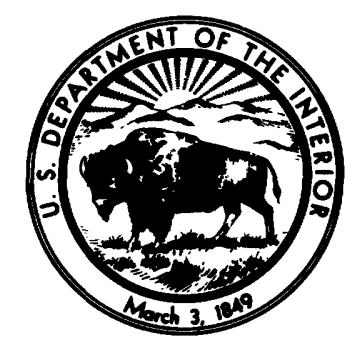


UNITED STATES DEPARTMENT OF THE INTERIOR

CECIL D. ANDRUS, Secretary

GEOLOGICAL SURVEY

V. E. McKelvey, Director

Library of Congress Cataloging in Publication Data

Schlee, John Stevens, 1928-

Stratigraphy and Tertiary development of the continental margin east of Florida.

(Drilling on the continental margin off Florida)

(Geological Survey professional paper; $581-\mathrm{F}$ )

Bibliography: p.

1. Geology, Stratigraphic--Tertiary. 2. Geology--Atlantic coast (United States) 3. Continental margins--Florida.

I. Title. II. Series. III. Series: United States. Geological Survey. Professional paper; 581-F.

QE691.S34 551.7'8'0916348 76-608370

For sale by the Superintendent of Documents, U.S. Government Printing Office

Washington, D.C. 20402

Stock Number 024-001-02912-0 


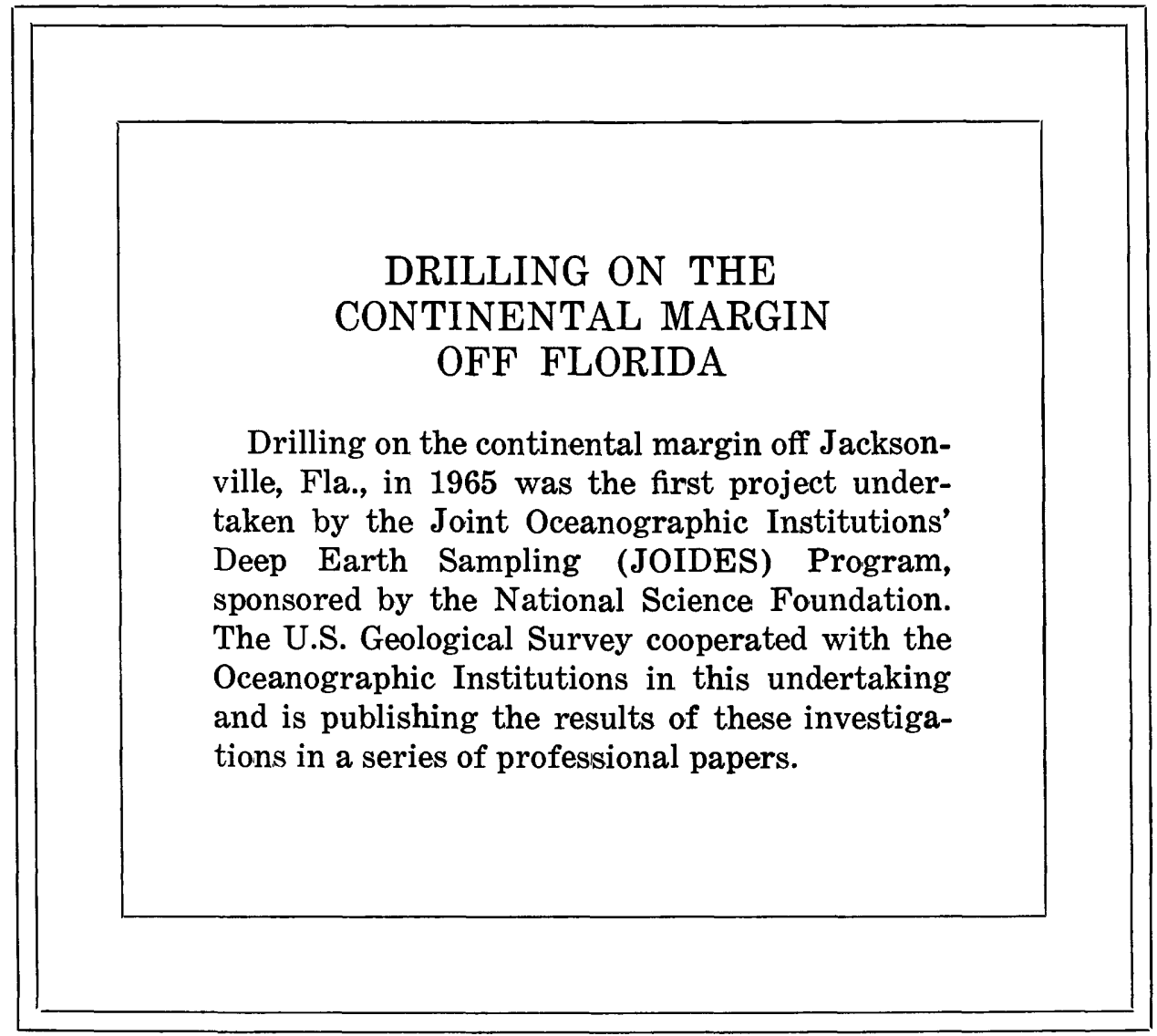





\section{CONTENTS}

Abstract
Introduction
Descriptive stratigraphy
$\quad$ Continental Shelf
$\quad$ Florida-Hatteras Slope
$\quad$ Blake Plateau
Paleontology
$\quad$ Rate of sediment accumulation
$\quad$ Paleoecology -

\section{ILLUSTRATIONS}

Plate 1. Stratigraphic profiles across the southeastern United States continental margin

FIGURE 1. Index map of continental margin off eastern Florida

2. Map showing main tectonic features of the southern United States and bordering continental margin ---

3. Diagram showing interpretation of continuous seismic-reflection profiles collected across the continental margin along a line of four drill holes

4. Stratigraphic sections to show the type of limestone and limy sediment of middle and late Eocene age cored in holes 1 and 2

5. Sketches of thin sections cut from rocks cored beneath the Continental Shelf

6. Sketches of the sedimentary structures in calcareous ooze of Oligocene age encountered in hole 5

7. Photomicrographs of thin sections from hole 4 and hole 3

8. Structure-contour map on the top of the Eocene Series

9. Schematic diagrams showing development of the Florida margin during the Cenozoic

\section{TABLES}

TABLE 1. Estimates of the amounts of minerals in samples, based on X-ray diffraction by Hathaway (Hathaway and others, 1971, table 1B)

2. Rates of sediment accumulation for selected biostratigraphic zones on the Blake Plateau and Florida-Hat-

3. List of calcareous nannoplankton indicative of nearshore shelf or basin milieu 


\section{METRIC-ENGLISH EQUIVALENTS}

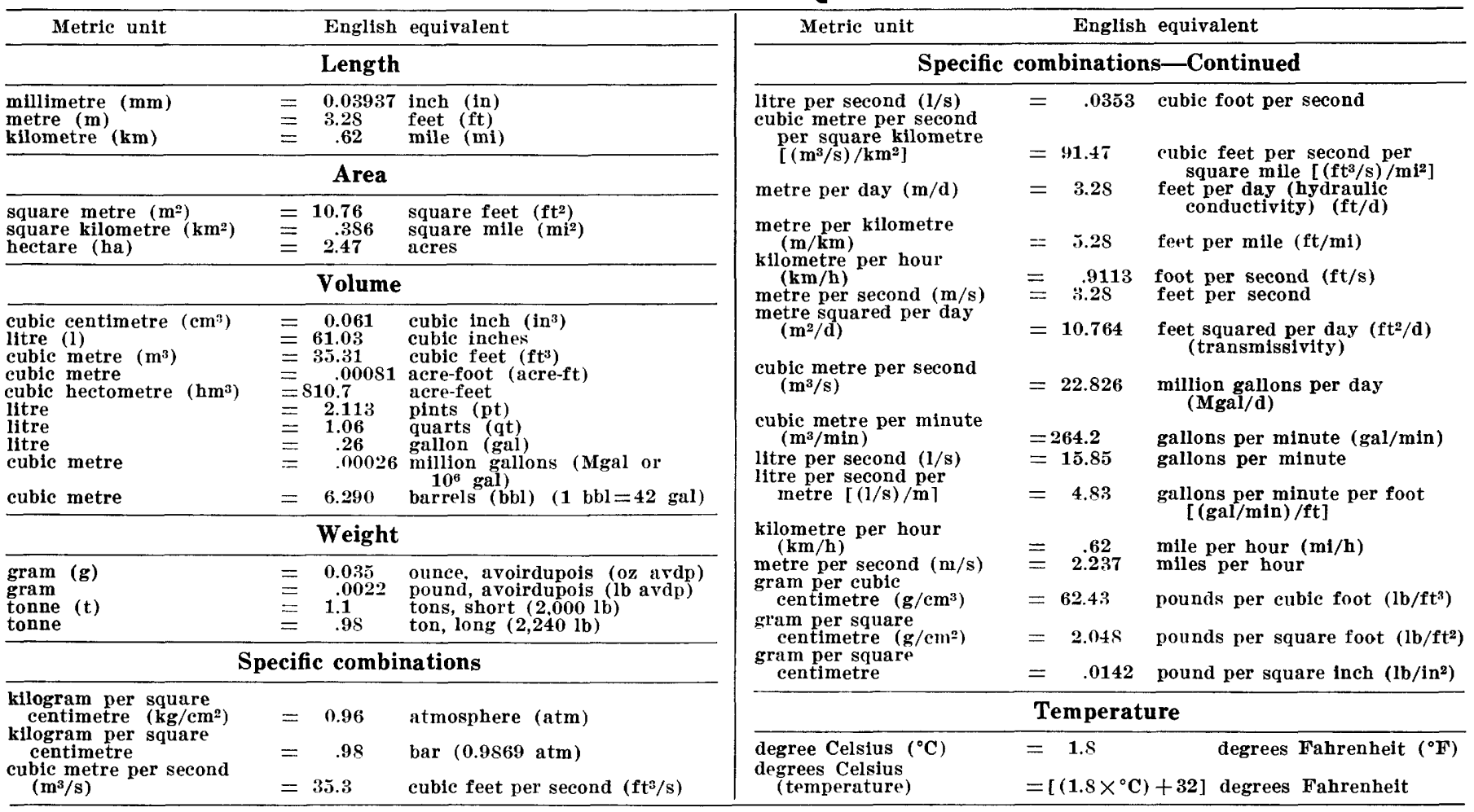




\title{
DRILLING ON THE CONTINENTAL MARGIN OFF FLORIDA
}

\section{STRATIGRAPHY AND TERTIARY DEVELOPMENT OF THE CONTINENTAL MARGIN EAST OF FLORIDA}

\author{
By JoHN SchleE
}

\begin{abstract}
Six holes drilled on the continental margin off eastern Florida reveal a continuity in age and a change in lithology between the rocks found offshore and those described from the Atlantic Coastal Plain. As on the land, pre-Miocene rocks are carbonate-limestone and calcareous ooze. The ooze is a deepwater deposit found mainly under the Blake Plateau and Florida-Hatteras Slope; it is a clayey to sandy, faintly mottled sediment composed of planktonic Foraminifera, coccoliths, Radiolaria, fine-grained carbonate, and lesser amounts of clay, ash, glauconite, and quartz. The limestone is a shallow-water grainstone and packstone under the shelf and siliceous carbonate mudstone under the Blake Plateau. Sediment of Miocene age grades from a mottled sandy silt and phosphatic clay nearshore to a calcarenitic ooze under the Blake Plateau. Nearshore, the Miocene Series appears to have accumulated in a restricted bay or lagoon; phosphate grains are concentrated in widespread distinct horizons and were transported prior to burial. On the Blake Plateau, a partially complete Miocene Series accumulated as a deep-water deposit, though the better sorting of the biogenetic debris suggests that the bottom was scoured by bottom currents-perhaps the ancestral Florida Current. Post-Miocene sediment is 20-50 m of shelly quartzose sand and silt on the shelf; seaward on the slope, it thickens to as much as $67 \mathrm{~m}$ of sandy to clayey calcareous ooze which unconformably overlies the Oligocene
\end{abstract} Series.

Formations of Eocene and Miocene age beneath the Coastal Plain continue seaward as recognizable units to the innershelf hole (42 km offshore). Beyond, changes in lithology make recognition of individual units difficult.

The stratigraphic sequence off eastern Florida is built over the Southeast Georgia embayment and the Blake Plateau trough. Except for minor warping on the inner part of the shelf during the Tertiary, the main structural framework (trough and basin) was already formed. The geologic record preserved is mainly a complex pattern of sedimentation and erosion over a gently subsiding margin. The broad outlines of bathymetry were already established by the beginning of the Tertiary; that is, the present deep-water areas were also deep-water areas during the Tertiary, and the FloridaGeorgia Shelf was a part of a broad platform that was emergent during the Oligocene. Active scouring by bottom currents on the Blake Plateau removed sediment of Eocene and Miocene age, or at least prevented its deposition for several million years. The efficacy of these currents is in- dicated by a diminished rate of sedimentation (less than 1 $\mathrm{mm} / 1,000$ years) in the lower Miocene and the excellent sorting of some of the deep-water cozes.

Sediment-accumulation rates on the Blake Plateau and the Florida-Hatteras Slope range from less than $1 \mathrm{~mm} / 1,000$ years to $36 \mathrm{~mm} / 1,000$ years. The rate is highest on the slope (hole 5) and in the oldest rocks (Paleocene) cored on the Blake Plateau. The winnowing of younger sediment on the Blake Plateau and the wide fluctuation of accumulation rates may indicate some shifting of the patterns of bottom currents over a period of time. The rates of sediment accumulation are similar to those noted by other investigators for deepwater areas of carbomate sedimentation, and they are decidedly less than those in noncarbonate depositional areas to the north during the Quaternary.

\section{INTRODUCTION}

In April and May 1965, six holes were drilled on the continental margin off eastern Florida as the first project of the Joint Oceanographic Institutions' Deep Earth Sampling Program (JOIDES) to sample the rock and sediment that compose the margin (Emery and Zarudzki, 1967). The area (fig. 1) was selected because geophysical surveys indicated that significant parts of the stratigraphic section might be sampled and might expand our knowledge of the geologic history of the margin. The purpose of this chapter is to discuss the lithology of the rocks penetrated in the six holes, in terms of the regional tectonic framework as it evolved during the Tertiary.

Topographically, the continental margin east of Florida differs from the typical shelf-slope-rise transition by the presence of a large deep-water plateau (Blake Plateau) that interrupts the Continental Slope at a depth of 500-600 m (Uchupi, 1968). The inner slope between the Blake Plateau and the shelf is called the Florida-Hatteras Slope; seaward of the plateau, the slope (Blake Escarpment) drops to a depth of more than $5 \mathrm{~km}$ in a distance of about $25 \mathrm{~km}$. The shelf east of Jacksonville is 100 to $130 \mathrm{~km}$ wide and slopes at a fraction of a 


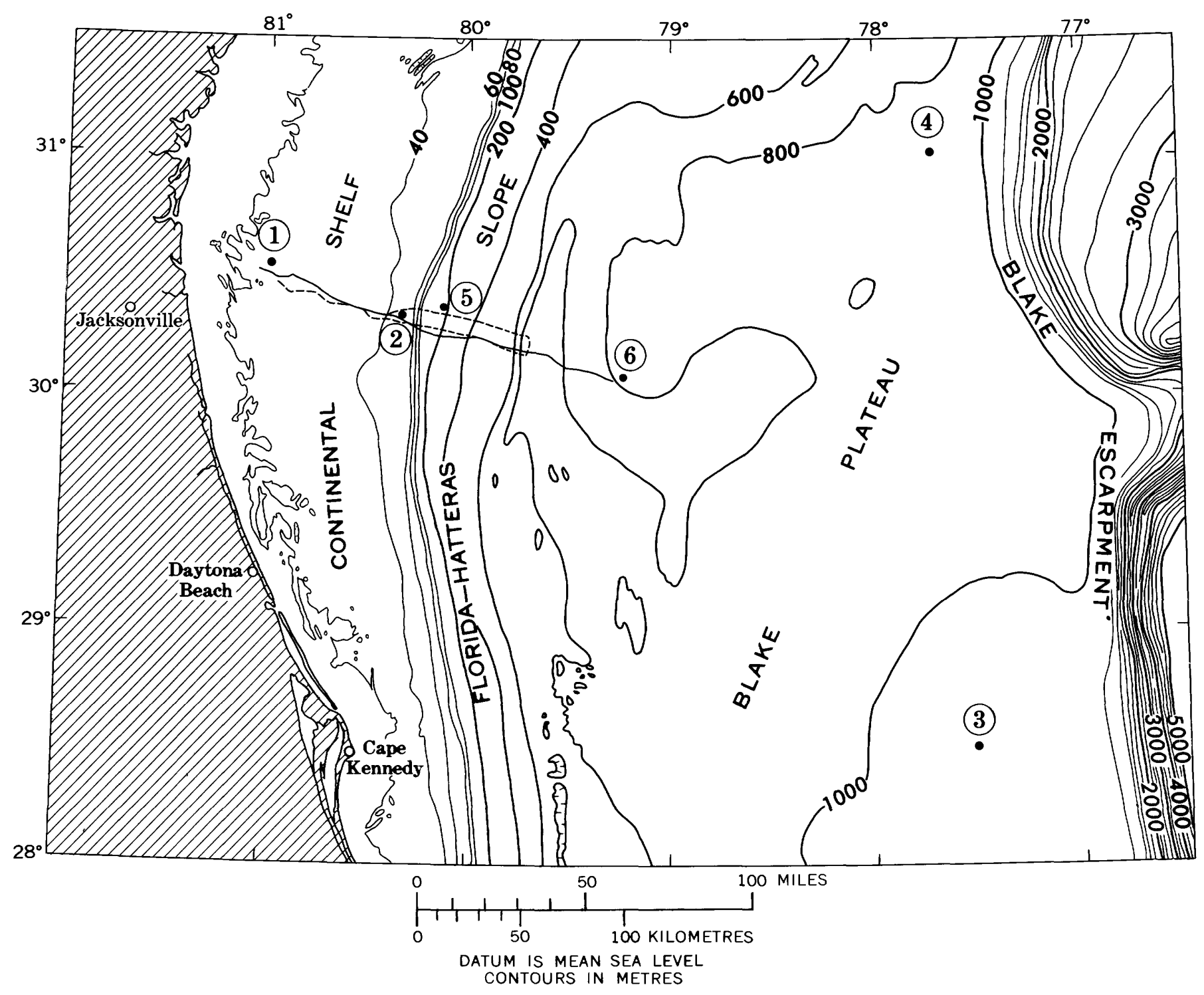

FIGURE 1.-Index map of continental margin off eastern Florida. Drill sites shown by dots. Solid line between holes 1 and 6 shows location of profile collected by Uchupi and Emery (1967) shown in figure $3 B$. Dashed line shows location of profiles collected by E. Bunce and S. T. Knott (Woods Hole Oceanographic Institution) and shown in a composite interpretative profile in figure $3 A$. Bathymetry from Uchupi (1968).

degree to the shelf break at approximately $60-\mathrm{m}$ water depth. Beyond, the Florida-Hatteras Slope dips about $11 / 2^{\circ}$ over a $30-45-\mathrm{km}$-wide area, to the western edge of the Blake Plateau. The plateau, a nearly horizontal platform $200-300 \mathrm{~km}$ wide, is characterized on its western edge by a series of elongate gentle depressions that have a relief of as much as $250 \mathrm{~m}$ (Pratt and Heezen, 1964, p. 724, fig. 1 ) and that are associated with coral banks (Stetson and others, 1962). To the east, at about 1,200-1,400$\mathrm{m}$ water depth, the sea floor drops off to the BlakeBahama Basin at a depth of $5,000 \mathrm{~m}$ in a distance of $25-35 \mathrm{~km}$ (average slope of $8^{\circ}$ ).
The Continental Shelf off Jacksonville is mantled with fine- to coarse-grained quartzose sand containing some shell debris. Beneath the Gulf Stream the outer shelf and Florida-Hatteras Slope are covered by silty Foraminifera-pteropod sand or ooze. The same area also shows spotty concentrations of glauconite and phosphorite in the bottom sediment. A medium- to coarse-grained Globigerina-pteropod sand (ooze) covers much of the Blake Plateau (Pratt and Heezen, 1964, p. 724 ; Milliman, 1972).

West of the study area (fig. 2), the Atlantic Coastal Plain is divided structurally into the Southeast Georgia embayment (Maher, 1971), bordered to the 


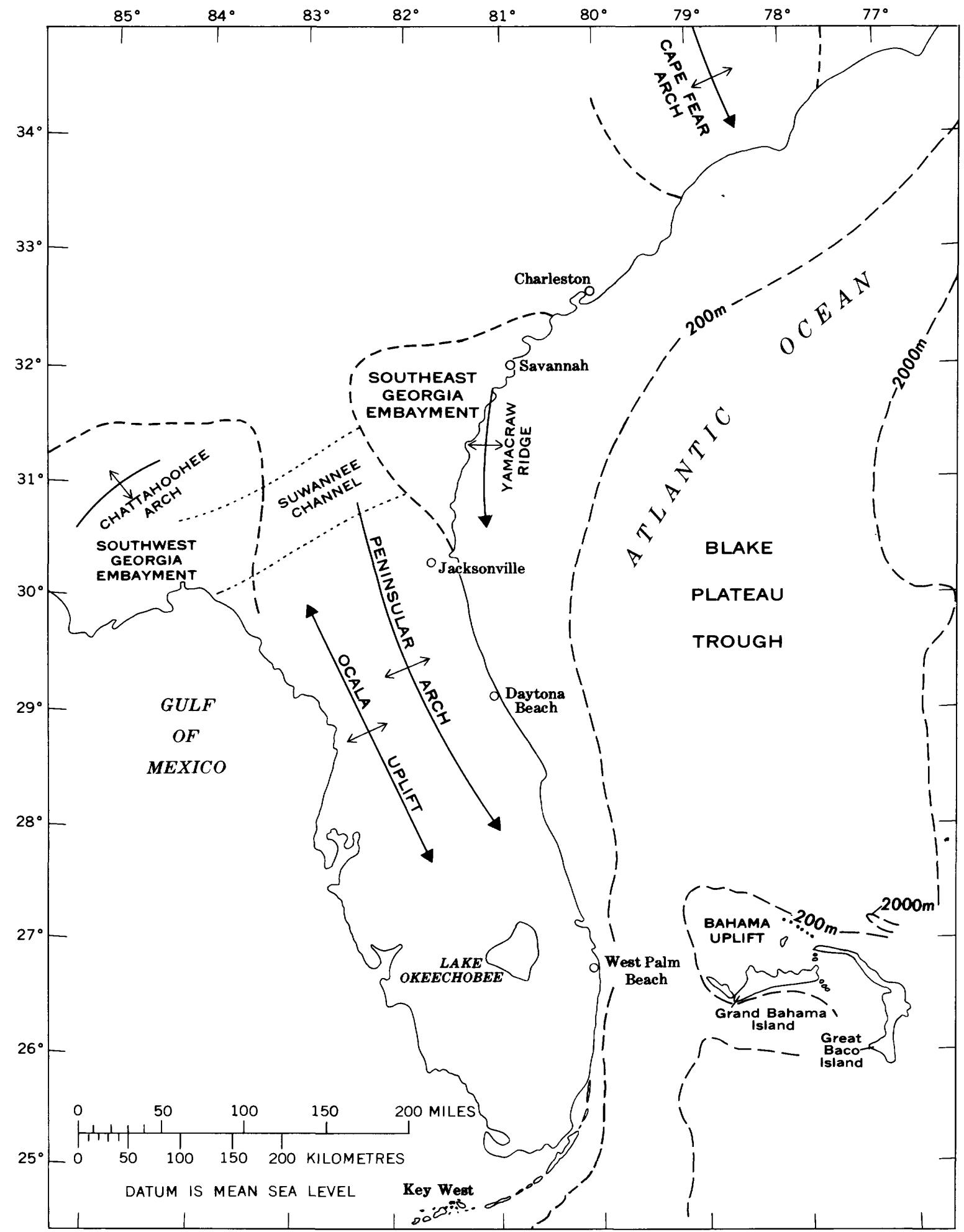

FIGURE 2.-Map showing main tectonic features of the southern United States and bordering continental margin.

north by the Cape Fear arch and to the south by the Peninsular arch. The embayment opens and deepens to the southeast. Strata of Tertiary and Cretaceous age tend to thin and become less rich in carbonate rocks to the northwest in central Georgia. They also thin to the southwest in Florida, where the section is mainly shallow-water limestones, part of the Florida Platform (Eardley, 1962, p. 666-667). 
The continuation of these rocks and structures beneath the continental margin has been inferred by geophysical studies (Hersey and others, 1959; Antoine and Henry, 1965; Bunce and others, 1965; Ewing and others, 1966), shallow-water offshore drilling (McCollum and Herrick, 1964), and deepwater dredging and coring (Ericson and others, 1952; Ericson and others, 1961; Stetson and others, 1962 ; Pratt and Heezen, 1964 ; Heezen and Sheridan, 1966 ; Sheridan and others, 1969 ; Emery and Uchupi, 1972). Seaward of the shelf, the basement deepens to more than $8 \mathrm{~km}$ (Emery and Uchupi, 1972) under the Blake Plateau in a broad, north-trending trough. According to Sheridan, Drake, Nafe, and Hennion (1966, fig. 5), a basement ridge bounds the eastern side of the trough, rising to within $3 \mathrm{~km}$ of the sea floor at the seaward edge of the plateau; Emery and Uchupi (1972) placed the top of the ridge at $6 \mathrm{~km}$ below the sea floor. Sheridan and coworkers (Heezen and Sheridan, 1966; Sheridan and others, 1969) described shallow-water limestone of Early Cretaceous age dredged from the lower part of the Blake Escarpment in two places; the limestone contains shallow-water benthonic Foraminifera and algae which led them to infer that the eastern Blake Plateau (as well as the northern Bahama Platform) was a shallow-water reef platform during this time. Piston cores have sampled deep-water oozes of Late Cretaceous and younger age (Ericson and others, 1952; Ericson and others, 1961; Sheridan and others, 1969; Emery and Uchupi, 1972) similar to what was drilled in the Blake Plateau holes.

Seismic-reflection profiles reveal a shelf that has prograded seaward and a section that thins beneath the slope (Bunce and others, 1965; Emery and Zarudski, 1967; Uchupi, 1970; Emery and Uchupi, 1972). The profiles (fig. 3) show a few persistent continuous horizons beneath the Florida-Hatteras Slope. The main older horizon (X) is sloping eastward on the upper profile $(A)$ and is nearly horizontal on the lower profile $(B)$. Reflectors on both profiles tend to pinch together beneath the slope, though pinching is more pronounced on profile $A$. Profile $B$ shows more evidence of erosion, in that the present sea floor appears to truncate older strata on the lower Florida-Hatteras Slope (fig. 3). Both profiles tend to show a steepening of the reflecting horizons beneath the slope and thereby indicate the probable existence of ancient continental slopes that are now buried because of seaward prograding of the slope. Emery and Zarudzki (1967) correlated some of the more prominent reflectors in the profiles with the drill-hole lithology from the JOIDES sites and
NW SE DISTANCE FROM SHORELINE, IN KILOMETRES
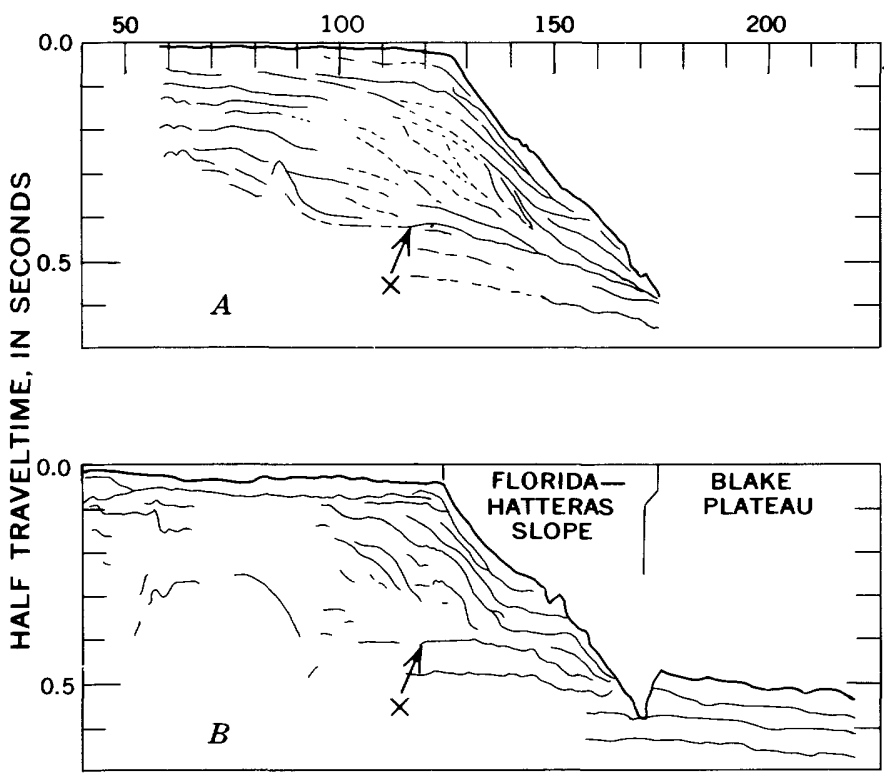

FigurE 3.-Diagrams showing interpretation of continuous seismic-reflection profiles collected across the continental margin along a line of four drill holes. $X$ is main older horizon. See figure 1 for location of profiles. From Emery and Zarudzki, 1967, figure 2.

found good agreement between some time-stratigraphic boundaries (Miocene, Oligocene, Eocene, Paleocene) and the reflectors, both on the slope and the Blake Plateau. Continuous seismic profiles on the eastern Blake Plateau (Ewing and others, 1966) show flat-lying strata close to the surface and deeper ones dipping to the west at a low angle.

These stratigraphic and geophysical studies show that the Blake Plateau trough was in existence at least as long ago as the Early Cretaceous, when, as in the areas to the west and south, a shallow carbonate platform existed, built over a differentially subsiding basement. The greater inferred thickness of Cretaceous and younger sediments toward the western Blake Plateau and the increased dip of older reflectors to the west (Ewing and others, 1966; Emery and Zarudzki, 1967) indicate a greater subsidence in that direction, perhaps along a series of border faults at the inner edge of the Blake Plateau; subsidence became more uniform during the Tertiary,

Many of my associates aided me during the cruise and in the preparation of the paper after the cruise. I am particularly indebted to K. O. Emery, Elazar Uchupi, W. A. Berggren, and R. C. Tjalsma (Woods Hole Oceanographic Institution); R. L. Wait, G. W. Leve, Eugene Shuter, W. S. Keys, R. H. Meade, Jr., 
J. C. Hathaway, S. M. Herrick, J. I. Tracey, Jr., Clyde Conover, and H. B. Counts (U.S. Geological Survey) ; Tbunemasa Saito and R. D. Gerard (Lamont-Doherty Geological Observatory); the late Louis Lidz (Institute of Marine Science, University of Miami), and H. S. Puri (Florida Geological Survey). On board the "Caldrill I," description and handling of the cores was facilitated by J. R. Frothingham, Jr., and K. O. Emery (Woods Hole Oceanographic Institution) ; F. T. Manheim and R. L. Wait (U.S. Geological Survey) ; Mark Salkind (LamontDoherty Geological Observatory); and Walter Charm and Herman Hofman (Institute of Marine Science, University of Miami). Helpful critiques of the manuscript were given by J. D. Milliman and O. H. Pilkey.

\section{DESCRIPTIVE STRATIGRAPHY}

\section{CONTINENTAL SHELF}

Tertiary rocks drilled on the shelf show lithologic changes both laterally and vertically. Eocene limestone changes from a well-sorted grainstone on the inner shelf to carbonate mudstone and wackestone under the Outer Continental Shelf. Vertically, Eocene and Oligocene carbonate deposits give way to Miocene phosphatic silt and post-Miocene sand and silty sand. The lateral changes relate in part to a shift in the site of deposition from a platform or shallow shelf to the outer shelf or upper slope. The vertical change to fine-grained terrigenous clastic deposits is probably due to major changes in the paleogeography of the area that permitted the influx of detritus and volcanic ash.

On the shelf, the Eocene section consists of wellindurated to poorly consolidated limestone and ooze. Though only rocks of middle and late Eocene age were drilled, they are similar to the Ocala Group (Avon Park Limestone and Lake City Limestone) of northern Florida. The sequence is as calcareous as the overlying Oligocene sequence but is much coarser grained and is better sorted. Recovery of the Eocene rocks was about the poorest of all the time-stratigraphic units cored on the shelf, mainly because of an inability to recover hard dolomitic limestone in the coring apparatus (John Schlee and Robert Gerard, unpub. data, 1965).

Limestones of middle Eocene age are porous, dolomitic, fine- to coarse-grained packstone and grainstone (classification of Dunham, 1962). They are pale yellowish gray $(5 Y 8 / 2 ; 2.5 Y 8 / 2),{ }^{1}$ punky to

1 Color designations are based on the Rock Color Chart of the National Research Council (Goddard, 1948). hard, and composed of a bioclastic framework of milliolid Foraminifera, coralline algae, and shell fragments. Vugs as much as several millimetres in diameter are lined with small euhedral rhombs of calcite and dolomite. Dolomite also occurs as strawyellow clusters of crystals intergrown with the calcite. Scattered flecks of a black carbonaceouslike substance in the limestone of hole 1 are similar to those found in the Lake City Limestone and the Avon Park Limestone in Florida. In hole 2, less section was drilled than in the nearshore hole, but the section showed a similar sequence of dolomitic and nondolomitic limestone; much of it consists of massive porous grainstone, again having a bioclastic framework of shell debris, algae, and Foraminifera. Scattered glauconite is also present, particularly near the boundary between limestones of middle and late Eocene age.

The limestone sequence of late Eocene age correlates with the Ocala Limestone of Florida and Georgia. In hole 1 , it is mainly packstone in the lower two-thirds and a grainstone in the upper onethird. The rock is massive, dolomitic, hard to friable, fine to coarse grained, and contains scattered grains of glauconite. Farther offshore (hole 2) the section is mainly packstone and lesser amounts of wackestone and calcareous ooze. The rocks are likewise massive, contain scattered grains of glauconite, and are composed of bioclastic fragments. When compared with the inshore hole, the sequence contains more matrix, less dolomite, and is less well indurated (fig. 4).

Obvious stratification and other sedimentary structures are lacking except in the upper part of the Eocene section at hole 2. Some cores showed faint mottling and a few zones of laminae. Most, however, could not be adequately described because of the homogenizing action of the drill bit in punky limestone: chunks of limestone several millimetres across were mixed in with calcareous ooze. In many cores, calcarenitic sand identical with the intercalated grainstone can be seen in the same core. Because of the close association of broken fragments of limestone and ooze, one gains the impression that some of the ooze is pulverized limestone created by the cutting action of the bit.

A thin section (fig. $5 \mathrm{~A}$ ) of a middle Eocene grainstone from hole 1 reveals a bioclastic framework of benthonic Foraminifera, coralline algae, broken pelecypod shell fragments, superficial ooids, pellets, and carbonate-rock fragments. The framework is well sorted, though it has a wide range in size from $3 \mathrm{~mm}$ to $1 / 16 \mathrm{~mm}$. Algae and shell fragments are 


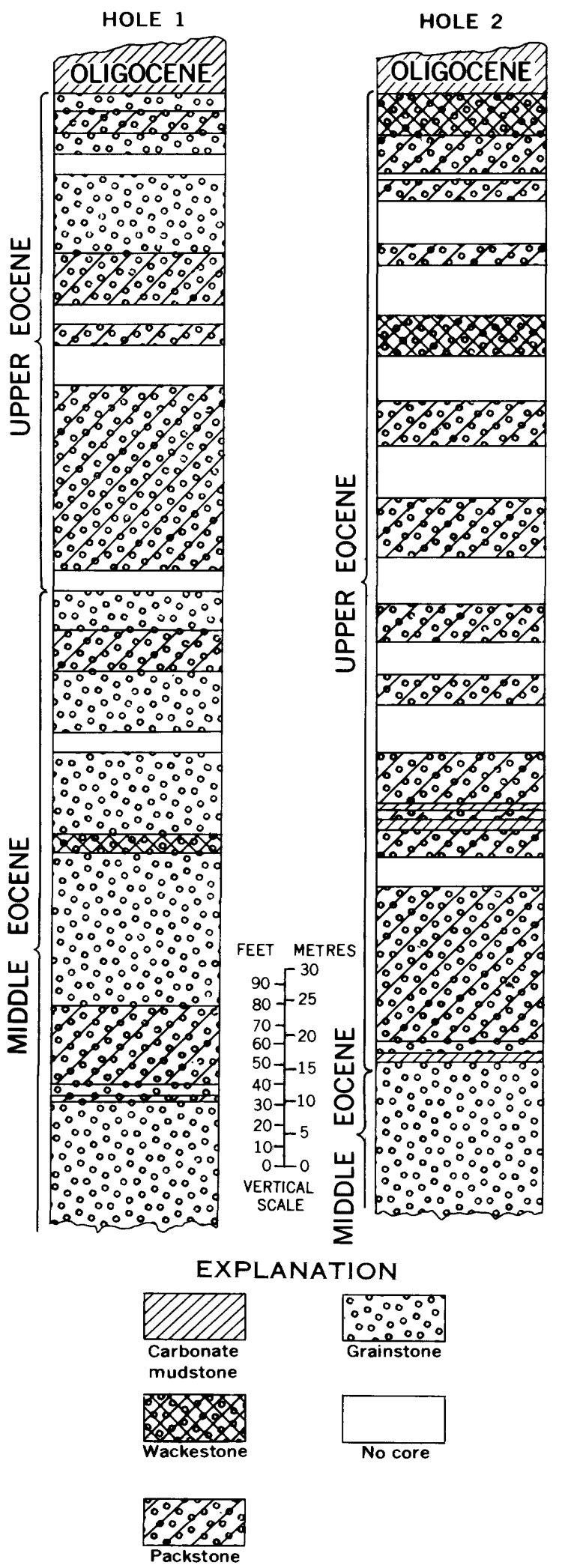

FIGURE 4.-Stratigraphic sections showing the type of limestone and limy sediment of middle and late Eocene age cored in holes 1 and 2 . See figure 1 for location of drill holes. Absence of core can be due to no recovery or to no attempt to core for a particular interval. rounded, as are the rock fragments; the rock fragments are a mixture of angular bioclastic debris set in an impure matrix of micrite. Some Halimeda fragments are present along with massive well-rounded pellets of micrite. The broken nature of the thin pelecypod shells, the rounding of pellets and rock fragments, and the absence of much interstitial debris, suggests that the carbonate detritus was reworked and sorted prior to final deposition.

Interstices are filled mainly by calcite or dolomite. The bioclastic fragments may be bordered by a thin coating of small crystals $(1 / 20 \mathrm{~mm}$ or less) or carbonate, both outside and within the chambers of the tests. Most interstices are filled by a coarsely crystalline carbonate $(0.1-0.4 \mathrm{~mm})$, though incompletely in some grainistones (fig. $5 \mathrm{~A}$ ). Some of the cement is dolomite, judging by the rhombic outline of the straw-yellow euhedral crystals and their index of refraction. The dolomite also forms elongate clusters and irregular patches that cut across the preexisting clastic texture and obliterate the internal structure of many carbonate tests.

Rocks of similar age in hole 2 were examined in only one thin section-a dolomitic grainstone, where extensive recrystallization has obliterated much of the bioclastic texture, particularly the delicate internal structure of Foraminifera. Bedding is still obvious as an imbrication of tabular fragments. The biogenic debris-particularly benthonic Foraminifera (discoid forms such as Lepidocyclina sp.), some globigerinid Foraminifera, coralline algae, mollusk shell fragments, glauconite, and pelmatozoan debris - forms about 15 percent of the sample. Most of the remainder is a carbonate mosaic (60 percent) and micrite (20 percent). The micrite occurs as scattered patches of dark-brown (in plain light) anhedral crystals (less than $0.01 \mathrm{~mm}$ ) of interlocking carbonate. The scattered isolated nature of the patches suggests that they are former pellets or algae debris that was compressed but not altered to coarsely crystalline mosaic.

The carbonate mosaic occurs as one of two modes, depending on the original bioclastic framework. In the nonglauconitic part of the rock, crystals are 0.2 to $0.07 \mathrm{~mm}$ across, subhedral, and tend to be interlocked with other crystals. In the glauconitic limestone, crystals are smaller $(0.1-0.05 \mathrm{~mm})$ and euhedral (rhombs) to subhedral; crystals are more scattered and are associated with micrite. The lack of a common orientation to the rhombic crystals and their presence in the matrix suggest that they may have grown at the expense of fine carbonate during diagenesis. 
Upper Eocene limestones in the outer-shelf hole contain a much higher percentage of matrix, fine planktonic bioclastic debris, and they are more poorly sorted than deposits of similar age in the landward shelf hole (fig. $5 B$ ). Most of the limestone is poorly consolidated wackestone or packstone in Dunham's (1962) classification. A micritic matrix (6070 percent) is the main component, containing scattered broken and whole tests of globigerinid Foraminifera, Bryozoa, glauconite, thin shells, pellets, quartz, and feldspar. Scattered clear rhombs of dolomite are also present. The ghostlike indistinct appearance of some biogenic debris suggests that much of it has been recrystallized. The recrystallization appears to have been selective, for small curved shardlike fragments of broken Foraminifera are preserved along with the coccoliths.

Except for a few wispy traces of bedding on one slide, the thin sections show no sedimentary structures. The faint suggestion of bedding is shown by the sorting and subparallel alinement of broken Foraminifera tests. Most sections reveal a haphazard mixture of Foraminifera $(0.5 \mathrm{~mm})$, cellular fragments of Bryozoa (?), and impure anhedral crystals of carbonate less than than $0.01 \mathrm{~mm}$ in diameter.

Noncarbonate constituents are quartz, glauconite, and an opaque coaly unknown mineral. The quartz (less than 5 percent) is usually in the same size range $(0.04$ to $0.08 \mathrm{~mm})$ as much of the carbonate detritus; it is angular, and the grains may show ragged boundaries with carbonate, suggestive of corrosion of quartz in a high pH setting. The glauconite (trace to 2 percent) occurs as green irregular clusterlike grains associated with opaque black organic (?) masses (0.01 to $0.03 \mathrm{~mm}$ in diameter) in shell tests. The close association of the black organic(?) material, glauconite, and shell tests suggests that perhaps the organic material helped to provide a reducing environment conducive to the formation of the glauconite. The brownish-black organic substance also occurs by itself as small irregular masses in the cell structure and interstices of biogenic debris. Coarse carbonate detritus is present in minor amounts (less than 5 percent), as large Foraminifera (discoid forms like Lepidocyclina sp. and Operculinoides sp.), pelecypod shell fragments, Bryozoa fragments, and pellets. These forms are scattered among finer carbonate and noncarbonate debris; the shell fragments and a few of the large Foraminifera are broken, suggesting some transport prior to final incorporation into the carbonate mud. Many of these larger fragments show extensive recrystallization, as indicated by the fuzzy boundaries with micrite, and a loss of the fine detail of shell structure. Other fragments such as pelecypod shells are unaffected and still show the delicate laminations they acquired during growth.

The matrix (fig. 5B) is a mixture of dusty anhedral pale-yellow crystals of carbonate, faint relict outlines of coarser fragments $(0.04-0.06 \mathrm{~mm})$, shardlike fragments of Foraminifera, and noncarbonate particles. The fine biogenic debris is mainly planktonic Foraminifera, coccoliths, and unidentifiable material that probably has resulted from the breakup of whole tests.

The poor sorting of these limestones suggests a pelagic contribution of skeletal debris and limited winnowing. At least some evidence for current activity is indicated by accumulations of better sorted fragments, the mixing of terrigenous and shallowwater detritus with the planktonic forms, and the presence of thin-shelled benthoslike Hankenina primitiva.

The shelf holes indicated a gradual change seaward of the upper Eocene section from grainstone and packstone that formed on a slowly subsiding shallow carbonate platform, to wackestone, packstone, and carbonate mudstone that formed in an outer shelf milieu where the planktonic fraction was a more significant contribution and the currents were weak enough to permit the accumulation of fine detritus. Some transport offshore is indicated by the presence of quartz and by the presence of benthonic forms more typical of a shallow environment.

The Oligocene section thickens seaward from 9.2 $\mathrm{m}$ (hole 1) and $28.1 \mathrm{~m}$ (hole 2), to $162.1 \mathrm{~m}$ under the upper part of the Florida-Hatteras Slope (hole 5) ; in all three holes, it is massive or faintly mottled, pale-olive $(10 Y 6 / 2)$ clayey to silty plastic calcareous ooze. The mottling is irregular and swirllike, though some mottles are oval in cross section and are interconnected, imparting a burrowed aspect. A few laminae or very thin beds, $1 \mathrm{~mm}$ to $3 \mathrm{~cm}$ thick, are in sequences $1 / 3$ to $2 / 3 \mathrm{~m}$ thick. Grain size ranges from very fine sand to silt and clay. The coarsest detritus consists of fragments of Foraminifera, glauconite, and scattered phosphate-the last two components are more prominent toward the base of the section. The matrix (table 1, J-1-345) is made of tiny anhedral irregular grains of impure cloudy carbonate. Scattered through the matrix are the tests of globigerinid Foraminifera, angular quartz, and trace amounts of glauconite, zircon, and penninite. The coarsest fragments are in the coarse silt range, and there is no evidence of sorting or of a preferred arrangement of the larger fragments. The total as- 

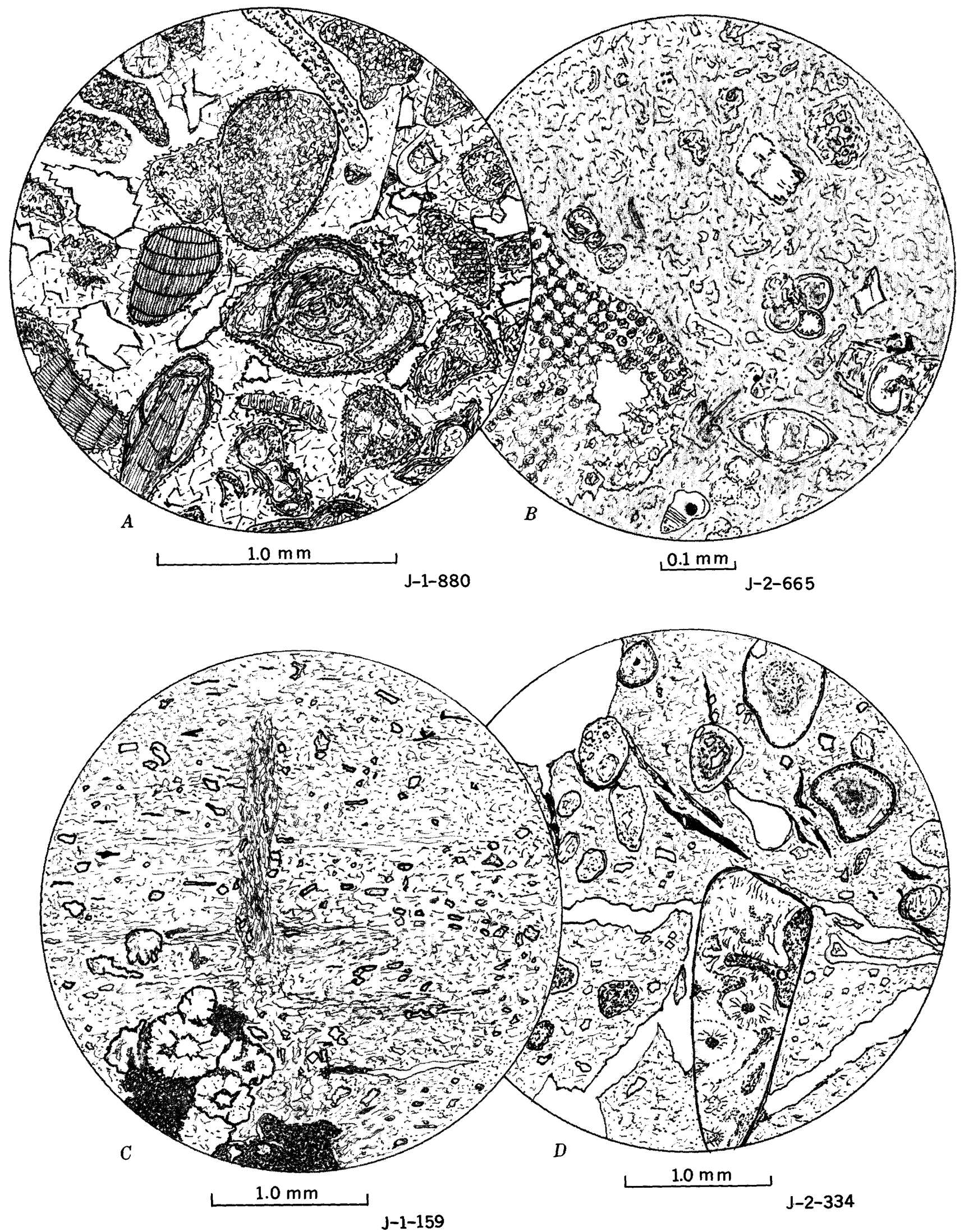
TABLE 1.-Estimates of the amounts of minerals in samples, based on X-ray diffraction by Hathaway (Hathaway and others, 1971 , table $1 B$ )

Most samples are consolidated and have had petrographic examination in thin section. See text.

JOIDES; the number that follows is that for the hole; is for the depth in feet below the sea floor.

Age: QT, post-Miocene

Tm, Miocene undifferentiated $\quad$ Tol, late Eocen

Tml, late Miocene

Tmm, middle Miocene

Tme, early Miocene

Tem, middle Eocen

Tee, early Eocene

Tp, Paleocene

\begin{tabular}{|c|c|c|c|c|c|c|c|c|c|c|c|c|c|c|}
\hline \multirow[b]{2}{*}{$\begin{array}{c}\text { Sample } \\
\text { No. }\end{array}$} & \multirow[b]{2}{*}{ 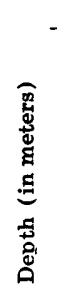 } & \multicolumn{13}{|c|}{ Consolidated materials } \\
\hline & & 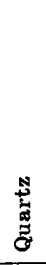 & 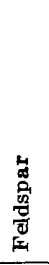 & 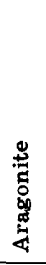 & $\begin{array}{l}\stackrel{\$}{0} \\
\text { J } \\
\text { J }\end{array}$ & 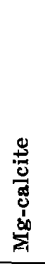 & 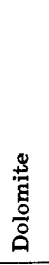 & 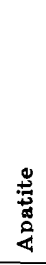 & 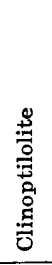 & 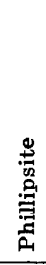 & 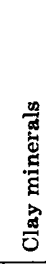 & 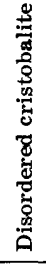 & 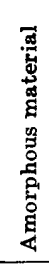 & $\begin{array}{l}\text { s. } \\
\text { పే }\end{array}$ \\
\hline 159 _. Tm & 48 & 2 & 2 & -- & & -- & 1 & -- & -- & -- & 5 & -- & -- & - \\
\hline $45--\frac{T 0}{T 0}$ & $\begin{array}{l}105 \\
110\end{array}$ & 3 & -- & -- & $\begin{array}{r}7 \\
10\end{array}$ & -- & -- & -- & -- & -- & -- & -- & 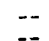 & -- \\
\hline $\begin{array}{l}-360 \\
-425\end{array}$ & $\begin{array}{l}110 \\
130\end{array}$ & $=$ & -- & $=-$ & 10 & $=$ & $=$ & $=-$ & $=$ & $=-$ & -- & $=$ & $\overline{--}$ & $=-$ \\
\hline-665 - Tem & 203 & $=$ & - & $=$ & 9 & $=-$ & $\overline{T r}$ & $=$ & -- & - & -- & - & -- & - \\
\hline $\begin{array}{ll}-780 & - \text { Tem }\end{array}$ & $\begin{array}{l}238 \\
268\end{array}$ & -- & -- & -- & $\begin{array}{l}10 \\
10\end{array}$ & -- & -- & -- & -- & - & -- & -- & -- & -- \\
\hline $\begin{array}{l}1-880 \\
2-334\end{array}-$ Tme & $\begin{array}{l}268 \\
102\end{array}$ & $\overline{\mathrm{Tr}}$ & $\overline{\mathrm{Tr}}$ & -- & 10 & $=$ & -7 & $\overline{2}$ & -- & -- & $\overline{\mathrm{Tr}}$ & -- & $=-$ & $=-$ \\
\hline$-665 \ldots \mathrm{Tel}$ & 203 & $\operatorname{Tr}$ & - & -- & 9 & -- & - & -- & -- & -. & $\ldots$ & -- & -- & - \\
\hline $2-775 \quad-$ Tel & 236 & & -- & -- & 7 & -- & 2 & -- & $\operatorname{Tr}$ & -- & -- & -- & -- & -- \\
\hline $2-891 \quad-\quad$ Tel & 272 & $\operatorname{Tr}$ & -- & -- & 8 & -- & $\operatorname{Tr}$ & -- & 1 & -- & -- & -. & -- & -- \\
\hline $2-1010-$ Tem & 308 & -- & -. & -- & 4 & -- & 6 & -- & -- & -- & $\because$ & -- & -- & 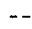 \\
\hline 0 - - Tme & 76 & -- & -- & -- & 9 & -- & -- & -- & -- & -- & 1 & $-\bar{c}$ & -- & -- \\
\hline $\begin{array}{l}-530 \\
-243\end{array}$ & 162 & 2 & -- & -- & 2 & -- & -- & -- & -- & -- & $-\overline{8}$ & 6 & -- & -- \\
\hline $\begin{array}{l}-243 \\
-280\end{array}-$ Tee & $\begin{array}{l}74 \\
85\end{array}$ & $\overline{\mathrm{Tr}}$ & $\begin{array}{l}-- \\
--\end{array}$ & -- & 5 & $=$ & $\begin{array}{l}-- \\
--\end{array}$ & $\begin{array}{l}-- \\
--\end{array}$ & $\overline{1}$ & -- & $\therefore$ & $\overline{3}$ & -- & $=-$ \\
\hline$\ldots \mathrm{Te}$ & 87 & $\mathrm{Tr}$ & -- & -- & 1 & -- & -- & -- & -- & -- & -- & 8 & -- & -- \\
\hline $\begin{array}{l}\mathrm{J}-4-348--T p \\
\mathrm{~J}-4-517 \mathrm{~B}-\end{array}$ & $\begin{array}{l}106 \\
158\end{array}$ & $\frac{2}{\operatorname{Tr}}$ & -- & -- & $\frac{1}{2}$ & -- & -- & $\ddot{--}$ & -- & -- & -- & 8 & -- & - \\
\hline $\mathbf{H}-\mathbf{T p}$ & 164 & $\mathrm{Tr}$ & -- & -- & 3 & -- & - & -- & -- & .. & -- & 7 & -- & \\
\hline QT & & $\operatorname{Tr}$ & -- & -- & 6 & -- & 3 & -- & -. & -- & -- & -- & -- & $\cdots$ \\
\hline$-5-220 \quad$ QT & 67 & -- & -- & -- & 1 & -- & 8 & -- & -- & -- & -- & -- & -- & 11 \\
\hline J-5-240 - To & & $\operatorname{Tr}$ & -- & -- & & & & -- & $\operatorname{Tr}$ & -- & -- & -- & -- & -- \\
\hline $\begin{array}{l}-5-270 \\
J-5-285\end{array}$ & $\begin{array}{l}82 \\
87\end{array}$ & 1 & & -- & $\begin{array}{l}6 \\
9\end{array}$ & $\cdots$ & $\stackrel{3}{T r}$ & $\cdots$ & -- & -- & -- & -- & 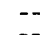 & \\
\hline J-5-318 & 97 & $\mathrm{Tr}$ & $\overline{T r}$ & -- & 6 & $=$ & $\operatorname{Tr}$ & 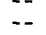 & -- & -- & -- & $\overline{2}$ & -- & 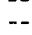 \\
\hline$J_{-5-596}^{J-6-318 \mathrm{H}}$ To & $\begin{array}{r}97 \\
182\end{array}$ & $\operatorname{Tr}$ & -- & -- & $\begin{array}{l}9 \\
8\end{array}$ & -- & $\mathrm{Tr}$ & -- & $\overline{\operatorname{Tr}}$ & -- & -- & - & 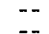 & \\
\hline$J-6-225-1-$ & & $\mathrm{Tr}$ & - & - & 6 & - & -- & - & -- & - & -- & 3 & -- & \\
\hline $\begin{array}{l}\mathrm{J}-6-225-2- \\
\mathrm{J}-6-325 \\
\mathrm{~J}-\mathrm{Tel}\end{array}$ & $\begin{array}{l}69 \\
99\end{array}$ & $\begin{array}{l}3 \\
4\end{array}$ & -- & -- & $\frac{1}{\operatorname{Tr}}$ & $=$ & -- & $\overline{-}$ & -- & -- & & $\frac{6}{5}$ & -- & \\
\hline - Tee & 114 & $\operatorname{Tr}$ & -- & -- & 4 & -- & -- & -- & -- & -- & -- & 6 & -- & -. \\
\hline J-6-388-2- Tp & $\begin{array}{l}118 \\
118\end{array}$ & $\overline{5}$ & $\begin{array}{l}-- \\
--\end{array}$ & $=$ & -- & -- & -- & $\because-$ & -- & $\begin{array}{l}-- \\
--\end{array}$ & -- & 5 & -- & \\
\hline
\end{tabular}

1 Gypsum.

Figure 5.-Sketches of thin sections cut from rocks cored beneath the Continental Shelf. Sample numbers are given below the sketch. The first number refers to the hole and the second to the depth in feet below the sea floor at which the sample was collected. $A$. Grainstone of middle Eocene age. A grain-supported framework of benthonic Foraminifera, coralline algae, pellets, and other carbonate debris is held together by coarsely crystalline carbonate cement that incompletely fills the voids. $B$. Wackestone of late Eocene age. Scattered small Foraminifera, quartz, and unidentified carbonate debris in a micritic matrix. $C$. Silty clay of Miocene age. Faint bedding shows up mainly as a subparallel alinement of tabular minerals and is intersected by a burrow(?). At lower left are spherulites of silica and opaque organic(?) debris. Table 1 gives the mineralogy of the matrix. $D$. Phosphatic sandy silt of Miocene age. Rounded sand grains of phosphate are set in phosphatic silty matrix. Grains are sporbo (rounded and having concentric bands) of collophane composite types (upper left) of phosphatized sediment and rounded fragments of fibrous dahlite (largest fragment, lower center). The latter type may be phosphatized on skeletal fragments. pect of the sediment is that of a hemipelagic ooze that shows little or no evidence of reworking; quartz and feldspar grains scattered throughout the ooze may have been transported by surface currents from land or more probably by the wind.

Sediments of Miocene age beneath the shelf grade from sandy silt above to a phosphatic clay interbedded with silt below. The section thins slightly toward the outer shelf, and the middle Miocene is absent (Bunce and others, 1965, table 2). The lithology in both holes is similar to that of the Hawthorne Formation beneath the Coastal Plain, though a discrepancy in age designation between the two areas exists (middle-early Miocene on the Atlantic Coastal Plain versus early and late Miocene on the outer shelf). The isoftness and cohesiveness of the finegrained sediment resulted in an average core recovery of $\mathbf{5 5}$ percent.

The upper one-quarter of the Miocene section is a light-olive-gray to grayish-olive $(5 Y 3 / 2-10 Y 3 / 2)$ plastic to compacted silt that is sandy, calcareous, quartzose, and micaeous. It is faintly mottled, and most of the irregular wisplike structures are shown by subtle changes in color; a few can be distinguished by both textural and color changes. Bedding ranges from a few centimetres to 1-3 $\mathrm{m}$ in thickness. The silt is coarse grained, has a very fine sand admixture, and contains major amounts of quartz and carbonate detritus-mainly Foraminifera tests and shell fragments. Minor constituents include phosphate grains, mica, and glauconite.

Below the silt is phosphatic silty clay which contains a few beds of very fine grained phosphatic sand or silt. Strata range from $11 / 3 \mathrm{~m}$ to $1 \mathrm{~mm}$ in thickness, though most are less than $25 \mathrm{~cm}$. Bedding is sharp, even though the layer may be only a few centimetres thick.

Though not abundant, the sedimentary structures are varied. Most are open irregular equant patches, or lenticular flattened wisplike bodies, or angular sharp flattened breccialike structures. Some of these structures are probably due to core flowage, but the presence of undisturbed laminations and worm burrows closely associated with the mottled layers suggests that some of the disturbance was caused by original reworking of the sediment by animals.

The silty clay (most of the section) is a plastic to crumbly sediment having a coarse fraction that consists of quartz, orangish-brown to gray grains of phosphate(?), and broken shell fragments as minor constituents. Trace amounts of glauconite are present along with scattered clusters of an iron sulfide mineral. The latter occurs in small dark-gray 
splotches in the clay; on closer examination, the splotches are discolored clay containing delicate clusters of a tarnished brassy-yellow mineral. The mineral is apparently not too stable, for attempts to preserve it for X-ray analyses were unsuccessful. A sulfide mineral is likely, judging by the strong odor of hydrogen sulfide in many of the cores of silty clay. Almost all the Miocene section is slightly calcareous, probably because of the finely divided bioclastic skeletal debris.

Stringers of phosphorite pebbles and grains are associated with silt and clay in hole 2. Several stringers bridge the silt-clay transition, and at least one occurs toward the base of the clay. The phosphorite is shiny, dark gray to black, and subrounded; clasts range from sand size to as much as $26 \mathrm{~mm}$ in length. Discrete phosphatic sand beds are less evident here than they are in the inner-shelf hole 1.

Internally, the pebbles are massive and fine grained; neither relict bedding nor radial internal structure is evident. The pebbles are composed almost entirely of a silt-clay matrix made of quartz, feldspar, carbonate, clay minerals, organic debris, phosphate minerals, and opaque detritus. Together, the quartz and feldspar range in size from 0.1 to $0.5 \mathrm{~mm}$, tend to be subangular, and are sparsely distributed through the pebbles. Carbonate occurs as coccoliths, Foraminifera tests $(0.1-0.2 \mathrm{~mm})$, and as finely scattered fragments $(0.3-0.01 \mathrm{~mm})$ in the matrix. Much of the remainder of the matrix is "collophane", opaque materials, and organic debris; the last two types are concentrated in larger amounts toward the edge of the pebble to give a faint concentric structure (fig. $5 D$ ). This dark diffuse layer and the shiny rounded exterior of the pebbles suggests that after their growth in silty clay, they were moved and abraded before final burial.

In thin section, the silty clay (fig. $5 C$ ) is mainly a matrix composed of very fine equidimensional aggregates of clay minerals in which are scattered angular grains of quartz, feldspar, and organic debris. The organic (?) debris (5-10 percent) occurs as opaque to deep-brown tabular or wishbone-shaped fragments; many have an internal cellular structure. The fragments are broken and moderately sorted. Also present in minor amounts are glauconite, muscovite, and silica spherulites. The individual spherulites are radial growths of clear anisotropic fibrous silica as much as $1 / 2 \mathrm{~mm}$ in diameter. They appear to have grown in place and to have concentrated impurities from the matrix as a nearly opaque mass at the edges of the cluster of spherulites (fig. $5 C$ ).
This same silty clay makes up much of the Miocene section in the outer-shelf hole, though with some important changes. In the outer-shelf hole, the clay is thinner ( $23 \mathrm{~m}$ as opposed to $57 \mathrm{~m}$ inshore) and has much less phosphatic sand. As inshore, the clay is faintly mottled or massive, phosphatic, and slightly calcareous. The cores show scattered burrows and a few thin even laminae; layering ranges from a few millimetres to $11 / 2 \mathrm{~m}$ in thickness. The same odor of hydrogen sulfide permeates the cores; in a few, an oily odor was apparent.

Post-Miocene sediments range from quartzose, shelly, fairly well sorted sand to less well sorted micaeous silt. Most of the section is unconsolidated, but in hole 2 some layers cemented by carbonate form a very coarse grained to medium-grained calcareous sandstone. Fine-grained silty sands are pale olive $(10 Y 5 / 2 ; 2.5 G Y 5 / 2 ; 10 Y 5 / 2)$, and coarser grained quartzose shelly sands are massive and light olive gray $(5 Y 5 / 2)$ to yellowish gray $(5 Y 7 / 2)$. Stratification is broad in form and shows mainly as abrupt changes in sediment texture; units range from $1 / 2$ to $1 / 3 \mathrm{~m}$ in thickness.

The post-Miocene section in the nearshore hole is $20 \mathrm{~m}$ thick and changes from a sandy phosphatic faintly mottled silt at the base of the section through a silty fine- to medium-grained calcareous quartzose sand above, to a fine to medium-grained wellsorted quartzose shelly sand at the surface. The sand contains mainly angular to subrounded clear to cloudy quartz (70-80 percent) and broken shell fragments (0-25 percent). Dark minerals, mainly as brown and dark-gray phosphorite and glauconite, compose as much as 20 percent of the sand; the phosphate grains are polished, well rounded, and similar in appearance to those found in the underlying Miocene. The silt is quartz, finely divided carbonate debris, and clay minerals. The transition to the finer grained sediments of the Miocene is gradational.

In the outer-shelf hole, the section is thicker and better consolidated but still mainly a sand. The surface sediment is coarse-grained moderately sorted sand composed of subangular to subrounded clear to limonite-stained quartz (50 percent), skeletal carbonate (25-30 percent) as pelecypod shell fragments and Foraminifera, and superficial ooids and pellets (15 percent). Recovery of the section at depth was extremely poor (less than 1 percent) so that information on lithology is limited; this particular hole was redrilled several times, and recovery of the post-Miocene section was poor in each attempt. The cuttings are mainly broken fragments 
of a calcareous quartzose medium-grained to very coarse grained sandstone. Some quartzose sand was obtained in the cored interval 29.5-38.7 $\mathrm{m}$ below the sea floor, but its stratigraphic position is not certain because of slumping in the hole during this drilling attempt.

Broken rock fragments recovered at depth are of two main types-fine-grained to very coarse grained quartzose calcareous sandstone, and medium-grained to very coarse grained limestone (calcarenite). Rock fragments as much as $40 \mathrm{~mm}$ across are mixed in with broken pelecypod shells, barnacles, gastropods, and sand dollars. The sandstone is well cemented by a carbonate cement, fairly well sorted, and composed of quartz and bioclastic debris. In some sandstone fragments, quartz grains are coated by carbonate layers to form superficial oolites. Moderately sorted bioclastic debris (as much as $3 \mathrm{~mm}$ in size), consisting of mollusk shell fragments, Foraminifera, and algae is found with the quartz. The limestone fragments are a microcoquina of coarse-grained to very coarse grained broken shell fragments, Foraminifera, and superficial oolites.

Unlike hole 1, hole 2 shows no grading to finer sediment toward the base of the section. The main change in the post-Miocene section seaward tends to be an increase in the amount of carbonate and in the degree of cementation.

\section{FLORIDA-HATTERAS SLOPE}

The Florida-Hatteras Slope is an area of major transition from a thickened section beneath the Continental Shelf to a thinned sequence under the Blake Plateau. (See fig. 3.) Marked changes in seismic velocities from refraction studies led Sheridan and others (1965) to infer faulting beneath this area, although no shallow faults were revealed by the reflection profiles. The slope also marks the region of inferred reef growth during the Pleistocene(?), though later sedimentation covered these structures (Zarudzki and Uchupi, 1968). The stratigraphic section cored beneath the Florida-Hatteras Slope (hole 5) reveals that the Oligocene Series is considerably thicker than that found on the shelf and that the Miocene is absent. A thick blanket of post-Miocene clastic sediment mantles the Tertiary System.

Sixteen metres of upper Eocene ooze was cored. It is a massive calcareous ooze and wackestone, firm to plastic, silty, and having a fetid odor. No thin sections were made of this unit, but it is similar in all respects to the overlying Oligocene Series. The boundary between the two series was not cored.
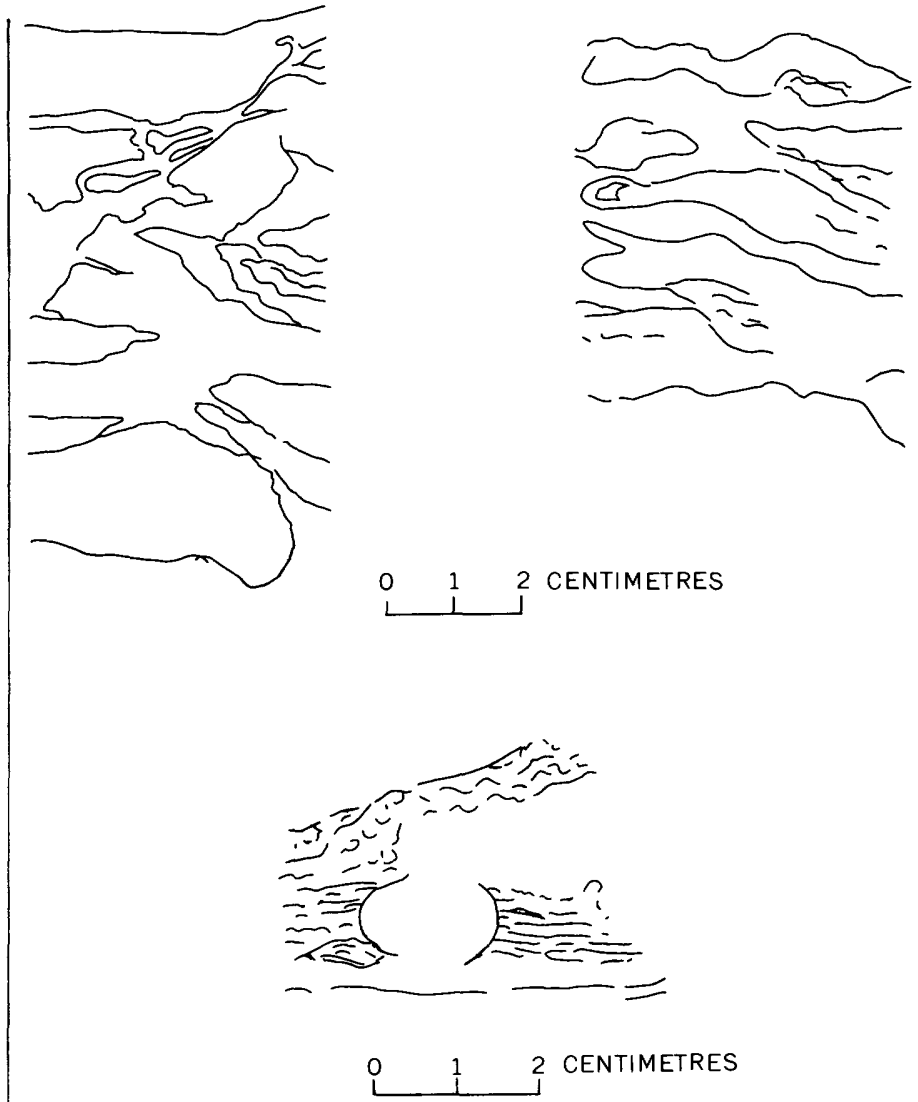

FiguRE 6.-Sketches of the sedimentary structures in calcareous ooze of Oligocene age found in hole 5 . Note the wispy discontinuous nature of the laminae in the upper two sketches and a burrow(?) that interrupts horizontal laminae in the lower sketch.

The Oligocene Series is approximately six times thicker here than in hole 2 (outer shelf), but the lithology is similar-mainly impure olive-gray ( $10 Y$ $6 / 1,5 / 2 ; 2.5 G Y 5 / 2$ ) carbonate mudstone interbedded with calcareous ooze. The ooze is plastic to crumbly, occurs as units as much as $2 \mathrm{~m}$ thick (though usually it is less than $1 \mathrm{~m}$ ), and is massive to faintly mottled or discontinuously laminated and burrowed over short distances (fig. 6). Some of the structures are similar to flaser bedding; others are vermiformlike structures suggestive of burrows. Clayey impurities of the ooze are indicated by an earthy odor (freshly opened core) and a weak reaction of the sediment to dilute hydrochloric acid. Later laboratory analyses revealed some clay (Hathaway and others, 1970, table 1) and smaller amounts of calcium carbonate (Charm and others, 1969, pl. 1) in comparison with the sediments of equivalent age on the Blake Plateau. Scattered through the ooze are dark-gray thin laminae of carbonaceous (?) minerals, some containing glauconite. Also scattered 
through it are a few pelecypod shells, some as much as $10 \mathrm{~mm}$ across. Interbedded with the ooze are layers of carbonate mudstone or wackestone that range from a few centimetres to several tens of centimetres in thickness; they are partly compacted to hard, massive, and similar in appearance to the ooze.

Petrographic slides of the ooze and the carbonate mudstone reveal a pale-yellowish-brown micritic matrix (60-80 percent) of anhedral carbonate crystals, and carbonate silt and bioclastic debris. Trace amounts of glauconite, quartz, and feldspar are scattered through the matrix. Carbonate silt fragments (10-30 percent) are angular to rounded, equant, cloudy to clear, and as much as $0.2 \mathrm{~mm}$ long. Many of the tests are broken, forming perforated shardlike fragments.

These sediments are mainly calcite (Hathaway and others, 1970, table 1) and lesser amounts of dolomite, quartz, and clinoptilolite. The only visual difference between adjacent layers of soft ooze and the carbonate mudstone seems to be that the micrite is clearer in the mudstone; X-ray diffraction analyses indicate that the mudstone lacks amorphous material (table 1, samples J-5-318, 318H). Further, the sediment samples contain a suite of clay minerals, lacking in the carbonate mudstone.

The general lack of sorting, the faunal association of Radiolaria and planktonic Foraminifera (Bunce and others, 1965), and absence of much terrigenous debris (Charm and others, 1969) indicate that the sediment accumulated well away from land in quiet water. The scarcity of laminations points to limited sorting of the pelagic debris by bottom currents, yet the burrowlike structures suggest that the debris probably was reworked by epibenthic fauna.

A major hiatus marks the boundary between postMiocene and Oligocene sediment. Though recovery was poor, short cores of a discontinuously laminated (laminae 1 to $8 \mathrm{~mm}$ thick) olive-gray (2.5GY 5/2) silty packstone were obtained at the boundary. Some of the laminae are quartzose; others contain scattered grains of glauconite and phosphorite. The large amount of dolomite (Hathaway and others, 1970, table 1) gives the rock a dense sugary texture and a conchoidal fracture. In thin section, the zone is a mosaic of dolomite rhombs and clay and trace amounts of glauconite and quartz (silt size). The dolomite is in clusters of yellowish cloudy rhombic crystals (0.03-0.06 $\mathrm{mm}$ across). A brownish mixture of clay and carbonate fills the areas between the clusters of dolomite. Some globigerinid Foraminifera debris is present in small amounts. The similarity in size of quartz, glauconite, and recognizable bioclastic debris probably indicates that the sediment was originally a fine-grained calcareous ooze similar to those already described. Some of the dolomite clusters may have originally been shell fragments.

Curiously, the Miocene Series is missing from this site, though scattered grains of phosphate are present at the disconformity and in the post-Miocene sequence above. The amount of phosphate concentrated along this disconformity is most obvious in the gamma-ray log (pl. 1) and suggests a lag deposit left there as a part of reworking of the upper slope during the post-Miocene.

The post-Miocene sequence consists of sandy to clayey ooze interbedded with massive very fine grained calcarenitic sand. The sand may be silty (as much as 30 percent silt-clay matrix), quartzose, and contains scattered mollusk shells, cup corals, phosphorite, and glauconite. Other sandy units are a biogenic hash of Foraminifera, shell fragments, echinoids, pteropods, and pellets; the units are poorly consolidated, have little internal stratification, and show good sorting. Charm and others (1969) noted a general increase in quartz and shell debris in the upper part of the section, and this change signified to them a shallow-water environment and closeness to land.

In summary, the stratigraphy from the one slope hole shows the transition to an off-platform milieu; some of the transition was detected in sediments of hole 2. The thickened section of Oligocene carbonate points to a shift of the main center of deposition from the Florida Platform to the ancestral FloridaHatteras Slope, and less scour by an ancestral Gulf Stream. The absence of the Miocene Series, in addition to phosphate concentrated at the hiatus and scattered through sediments of post-Miocene age, suggests that a more extensive deposit of Miocene age may have covered the slope but that it was eroded and some of the coarser detritus was left behind as a lag or was incorporated into the younger deposits.

\section{BLAKE PLATEAU}

The three holes drilled (fig. 1) on the Blake Plateau show a diminished section of Tertiary calcareous ooze intercalated with ash layers. The two major stratigraphic changes from the Continental Shelf are (1) a thinning of the Eocene and Miocene sections and (2) the change in lithology from shallow-water dolomitic limestone and terrigenous phosphatic silts and clays to deep-water calcareous silty 


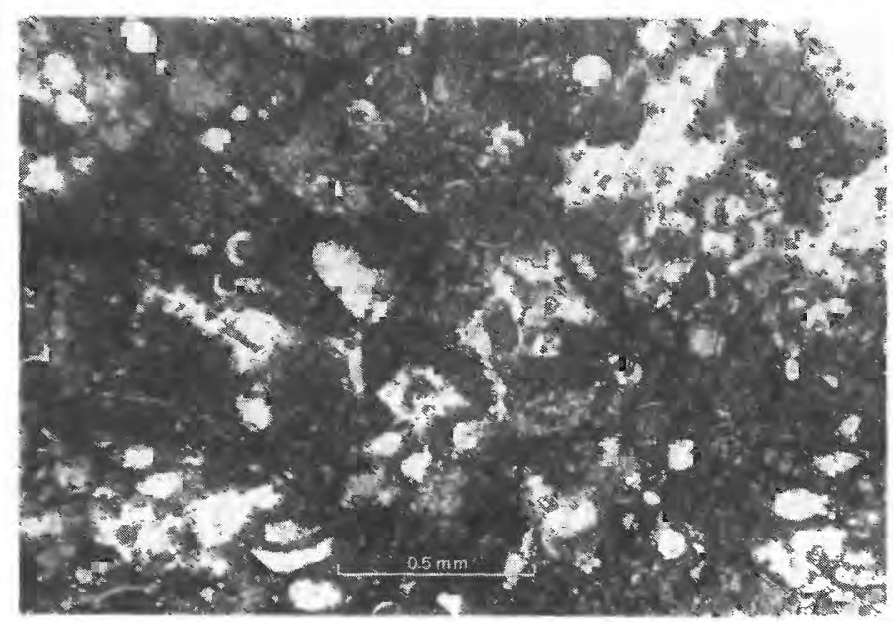

$\boldsymbol{A}$

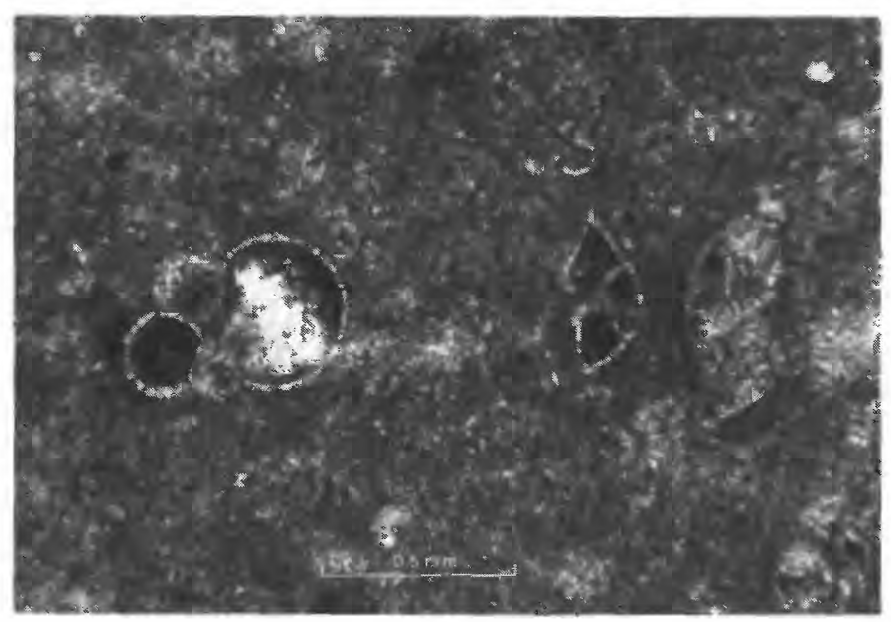

$B$

oozes, siliceous limestone, and chert (pl. 1). The thinned sequence indicates a slower rate of sediment accumulation and the presence of two unconformities; much of the Miocene is cut out along an unconformity that truncates the section to the west, and another unconformity truncates the Eocene section to the north and east. Low-angle truncation of the shallow reflectors is seen in one continuous seismic-reflection profile (Emery and Zarudzki, 1967, fig. 3) between holes 4 and 6 . The absence of any shallow-water fauna adjacent to the hiatuses (Bunce and others, 1965) indicates that the deepwater bottom currents either scoured previously deposited sediment or prevented sedimentation over a period of several million years.

In all three holes, a few thin beds of gray finegrained ash are intercalated with the calcareous ooze of Oligocene age. Additional thin ash layers also occur in Eocene sediments of hole 3 and possibly in

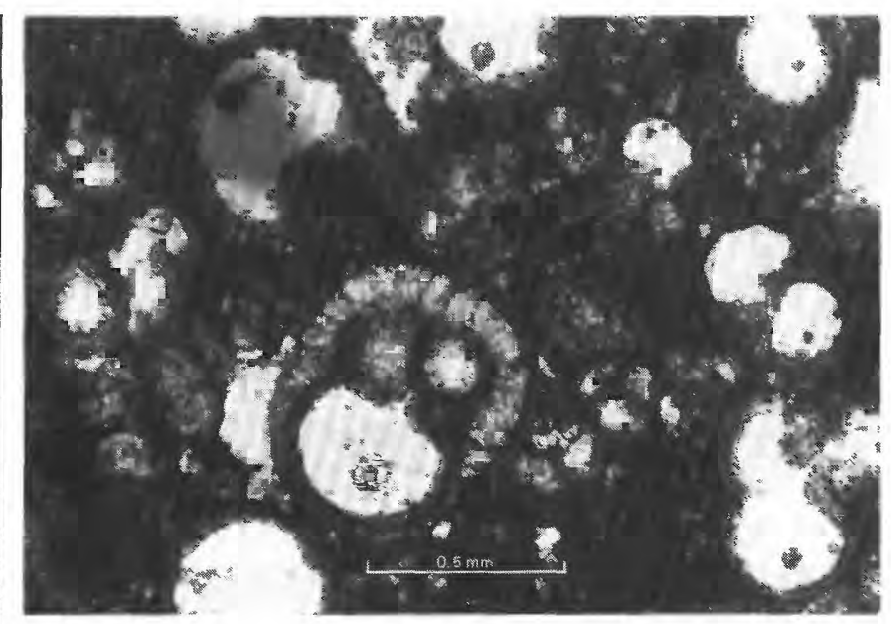

C

FIGURE 7.-Photomicrographs of thin sections from hole 4 and hole 3. $A$, Hole 4, cherty limestone (Paleocene), 348 feet $(106 \mathrm{~m})$ below sea floor, plane-polarized light. A calcareous ooze of matrix and planktonic Foraminifera has been selectively altered by silica, which forms irregular white masses extending into the slide from the upper right. $B$, Hole 4, calcareous ooze (Paleocene), 537 feet $(164 \mathrm{~m})$ below the sea floor, plane-polarized light. Thin-shelled planktonic Foraminifera in a carbonate matrix. $C$, Foraminifera grainstone (lower Miocene), 250 feet $(76 \mathrm{~m})$ below sea floor, plane-polarized light. Globigerinid Foraminifera packed together in matrix of broken calcareous bioclastic debris. Most tests are empty.

Miocene sediment of hole 4 . The preservation of these layers over such a wide area, yet their absence in holes drilled beneath the shelf and slope, suggests restricted reworking of the sediment by infauna and an absence of strong currents during the time they were deposited.

The oldest sediments penetrated in the drilling project were pale-grayish-yellow (10Y 7/1-5/1; $5 G Y 7 / 2$ ) calcareous oozes (fig. 7) and intercalated siliceous limestone (holes 5 and 6). The limestone is hard massive to indistinctly laminated impure mudstone and wackestone. It contains scattered grains of glauconite, pyrite, and Foraminifera. The limestone occurs as fragments within the ooze in the cores where recovery was poor. In a few cores, the ooze and limestone are interbedded in layers $5-8 \mathrm{~cm}$ thick, and the contacts are sharp. In hole 4, the siliceous limestone apparently provides enough of a density contrast with the overlying calcareous ooze to provide the shallowest reflector noted on continuous seismic-reflection profiles (Emery and Zarudzki, 1967).

Petrographic examination of the limestone reveals bioclastic debris (15-25 percent) scattered through 
an impure matrix of silica and carbonate (fig. $7 \mathrm{~A}$ ). The bioclastic fragments are globigerinid Foraminifera (3-12 percent) ranging from $0.4 \mathrm{~mm}$ to less than $0.1 \mathrm{~mm}$ and unidentifiable irregular lathshaped fragments of carbonate (9-13 percent), 0.05-0.2 mm long, probably broken remnants of larger tests. Also present is siliceous bioclastic debris (2-11 percent) as spines, Radiolaria, and shardlike fragments of larger unknown shells. Spherical cavities (less than $0.2 \mathrm{~mm}$ in diameter) lined or filled with silica, are scattered through the matrix and probably are replaced Foraminifera or Radiolaria.

The matrix (60-80 percent) is finely divided impure crystals of carbonate and silica (low-birefringent anhedral crystals). Some of the silica forms mosaics of interlocking crystals $(0.02 \mathrm{~mm}$ across $)$, but most is associated with the carbonate. X-ray diffraction analysis (hole 4 , table 1 ) shows these siliceous limestones to be about two parts calcite and seven or eight parts disordered cristobalite (scale of $10)$.

The calcareous ooze is an unconsolidated to partly compacted clayey to silty sediment, massive to faintly mottled, and containing scattered Foraminifera, glauconite, and mica (fig. $7 B$ ). Except for the induration, the ooze is similar in appearance to the limestone. The one thin section made of the ooze showed a texture similar to that of the limestone, the same scattered Foraminifera and circular voids; the latter are filled with a carbonate matrix and yellowish-brown to black opaque fragments. Most of the sediment (92 percent) is a matrix of calcite and minor amounts of clinoptilolite and quartz (Hathaway and others, 1970, table 1). The calcite is finely divided irregular fragments mixed in with unidentified impurities. The obvious finely crystalline mosaic of silica present in the limestone is lacking here as is the siliceous bioclastic debris.

All three holes on the Blake Plateau contain calcareous ooze of Eocene age, though the section is most complete and thickest $(62 \mathrm{~m})$ to the west in hole 6. The sequence is similar in lithology to the Paleocene section in that it consists of clayey to silty white calcareous ooze containing firm to hard beds of siliceous limestone and chert. Also present in hole 3 are two thin gray beds of volcanic ash.

The calcareous ooze is white $(N-9)$ to pale yellowish gray $(5 G Y 8 / 1 ; 5 G Y 6 / 2)$, unconsolidated to plastic, massive to faintly mottled, and has discontinuous laminations. The silty fraction is composed of planktonic Foraminifera, scattered grains of glauconite, coccoliths, spines, and Radiolaria. The
Eocene ooze is mainly calcite and minor amounts of montmorillonite and clinoptilolite (Hathaway and others, 1970).

The interbedded siliceous limestone and calcareous chert grade into the ooze. They are pale-yellowish-gray $(5 Y 8 / 1 ; 5 Y 7 / 2)$ to white $(N-9)$ to light-green $(5 G Y 6 / 2)$ rocks having a massive chalky appearance and a conchoidal fracture. Carbonate tests make up as much as one-fourth of the limestone and are mostly globigerinid Foraminifera, $0.3 \mathrm{~mm}$ or less in size; a few pteropod(?) shell fragments as much as $2 \mathrm{~mm}$ long are also present. To a large degree, much of the carbonate has been recrystallized, thereby obliterating internal shell structure. Where present, internal fillings of the Foraminifera are usually a finely crystalline carbonate mosaic similar to that in the matrix. However, some of the tests are filled with clay or a mixture of clay, carbonate, and silica. The degree of silicification varies from hole to hole in the Eocene section, but it seems most abundant in rocks of hole 3 . Bioclastic debris is silicified in a variety of ways. For some fossils, the silica appears to be pseudomorphous after calcite and to duplicate the internal shell structure with a mosaic of small crystals. In others, it forms a coarsely crystalline mosaic of interlocking crystals. Mixed in with the altered debris are siliceous forms such as radiolarians and diatoms along with the spherical silica-filled cavities already described in the rocks of Paleocene age (Hathaway and others, 1970 , fig. $8 B$ ).

In addition to the biogenic detritus described above, most of the rocks contain a carbonate-silica matrix and unidentifiable bioclastic detritus $(60$ 90 percent). Much of the detritus is broken tests grading to forms that have been recrystallized to irregular clumps of finely crystalline carbonate and silica. Angular grains of quartz and feldspar are present in trace amounts, along with rounded grains of glauconite about $0.1 \mathrm{~mm}$ in diameter.

The composition of the matrix is calcite, disordered cristobalite, and clay as mainly montmorillonite, illite, and clinoptilolite (Hathaway and others, 1970, pl. 1). In thin section, an impure micrite grades into broken shell fragments that are in the coarse silt range; it occurs mainly as irregular tabular fragments (less than $0.05 \mathrm{~mm}$ ) and darkgrayish-brown impurities impart a cloudy aspect to the section. These impurities are the disordered cristobalite and the clay minerals mentioned above. In hole 4 , the clinoptilolite appears as small laths (less than $0.01 \mathrm{~mm}$ long). Silica occurs as dark-grayish- 
brown anhedral crystals of disordered cristobalite and quartz $(0.05 \mathrm{~mm}$ in diameter $)$.

Two ash beds were penetrated in Eocene sediment of hole 3 ; the upper is a light-gray bed $5 \mathrm{~cm}$ thick that has a sharp contact below and a gradational one above. The other bed (approx. $170 \mathrm{~m}$ below the sea floor) is $3 \mathrm{~cm}$ thick, compacted, silty, and has sharp boundaries.

The Oligocene Series on the Blake Plateau is a calcareous ooze similar to that drilled under the Florida-Hatteras Slope and in older sequences of the plateau. Siliceous limestone and chert are lacking, though the ash beds are more numerous. Thickness of the Oligocene Series ranges from $28.7 \mathrm{~m}$ (hole 4 ) to $64 \mathrm{~m}$ (hole 3 ). In holes 3 and 6 , the sequence is mainly a plastic clayey ooze, whereas in hole 4, it is a calcarenitic silty sand rich in Foraminifera. Silt- and clay-sized carbonate materials are most dominant (as much as 80 percent) in the lower part of the Oligocene Series of hole 4, but the fine detritus drops to 20 percent in the upper part. Fauna are mainly open ocean deep-water forms (Bunce and others, 1965; Charm and others, 1969).

The calcareous ooze is a silty pale-yellowish-gray $(N-9 ; 5 Y 8 / 1 ; 10 Y 9 / 1)$ plastic to crumbly sediment. It is massive, though some scattered laminations are present. Cores are marked by changes of induration from unconsolidated ooze to plastic or crumbly ooze in zones $1 / 2$ to $1 \mathrm{~m}$ thick. Incipient cementation also occurs as small carbonate lumps (as much as a few centimetres in diameter) scattered through the unconsolidated ooze.

Interbedded with the ooze are as many as seven gray ash layers (hole 3), 5 to $10 \mathrm{~cm}$ thick. In addition, volcanic glass was noted in the washed fraction of ooze studied for index fauna. The ash layers are massive and contain differing amounts of calcareous ooze. Contacts are generally sharp, and beds can be separated by only a few centimetres of calcareous ooze. Glass fragments are angular and clear to pale green and brown. Hathaway, McFarlin, and Ross (1970, p. E17) noted the presence of montmorillonite and clinoptilolite, which they felt may be alteration products of silicic volcanic ash; both types occur in minor amounts in core samples of Oligocene ooze analyzed by them for the same holes.

Foraminifera ( 5 percent) and unidentified broken carbonate tests ( 22 percent) are scattered through a carbonate-clay matrix. The Foraminifera $(0.4 \mathrm{~mm}$ or less in diameter) are filled by matrix, and their tests are largely recrystallized, though some internal shell structure is still preserved. Carbonate frag- ments are angular to rounded, cloudy, and though some have a cellular internal structure, many are structureless and have an indistinct boundary with the matrix. The matrix is mainly tiny anhedral crystals of calcite (less than $0.01 \mathrm{~mm}$ ) and clay impurities. Also scattered through the broken matrix are coccoliths and a few embayed equant grains of quartz. Except in hole 4, the fauna and the complete lack of sorting give evidence that the ooze is a pelagic deposit which accumulated with little reworking of the bottom by currents.

Miocene oozes are present only in holes 3 and 4 , the thickest and most complete section being in hole 3 ; except for one questionable layer, ash beds are missing. The ooze is a yellowish-gray $(10 Y R \quad 8 / 1$; $5 Y 8 / 2 ; N-9)$ calcarenitic sand of planktonic Foraminifera and has a silty carbonate matrix. The ooze is faintly mottled to massive, unconsolidated to partly compacted; some layers (a few centimetres to $1 / 2 \mathrm{~m}$ thick) are better compacted than others, though no visual textural or compositional change is apparent. The amount of matrix ranges from 40 to 60 percent; much of it is fine biogenic debris, mainly planktonic Foraminifera.

A petrographic slide (fig. $7 C$ ) reveals a framework of globigerinid Foraminifera (33 percent) and broken tests of unidentified biota (10 percent) set in a pale-brown matrix (35 percent) ; opaque minerals and cavities account for the remainder of the rock. In most of the larger Foraminifera tests, vestiges of the internal structure are still preserved; most chambers are unfilled, although a finely crystalline coating of carbonate lines the cavities. Foraminifera range from $0.6 \mathrm{~mm}$ across to juvenile forms $0.05 \mathrm{~mm}$ across. The small ones are filled micrite and merge almost imperceptibly with the matrix. Some of the matrix is made up of coccoliths, but most is impure micrite. Impurities are mainly clay (Hathaway and others, 1970 ; table 1) and scattered embayed quartz.

The post-Miocene ooze in all three holes is a medium- to coarse-grained foraminiferal sand on the surface that gives way at depth to a clayey ooze. The ooze is thinnest at hole 6 , an area where the axis of the Gulf Stream is centered; here, biogenic sand a few metres thick changes abruptly to clayey ooze of Oligocene age at depth. The thickest accumulation (hole 4-18.3 m) occurs well to the east of present Gulf Stream activity. The oozes are unconsolidated yellowish-gray $(10 Y R 6 / 4) ; 10 Y R ~ 8 / 4)$ medium- to coarse-grained Foraminifera-pteropod sands. The upper $11 \frac{1}{2} \mathrm{~m}$ is fairly well sorted and lacks much matrix; below that, the ooze has $30-40$ 
percent carbonate matrix. The sand fraction is mainly globigerinid Foraminifera and pteropods (as much as $30 \mathrm{~mm}$ long); the ooze contains some manganese oxide-coated fragments of limestone (foraminiferal calcarenite). The lack of fine carbonate detritus in the surficial sediments at the three drilling sites points to active reworking and transport of bioclastic debris by bottom currents; dives by submersible craft on the Blake Plateau attest to the strength and duration of these currents (Milliman and others, 1967).

In summary, the holes drilled on the Blake Plateau reveal a sequence of deep-water calcareous ooze that gives way at depth to siliceous limestone and chert. The microfauna from this sequence (Bunce and others, 1965) indicates deposition in a water depth similar to that which exists there now $(600-1,100$ $\mathrm{m})$. Bottom currents have apparently fluctuated widely in strength during the Tertiary-weak at times to permit the deposition of thin ash beds, and strong at other times to winnow and sort fine detritus and erode previously deposited carbonate mud.

\section{PALEONTOLOGY}

Studies made since the work of Saito and Lidz (Bunce and others, 1965) have modified only slightly the original boundaries delineated by them (Roth, 1970; Gartner, 1971) ; the main inferences relative to water depth and deep-sea unconformities remain unchanged. Cores from holes 3,4 , and 6 have been studied most intensively, mainly for zonation of the Foraminifera (Blow, 1969) and nannofossils (Bramlette and Wilcoxon, 1967; Roth, 1970; Gartner, 1971). These zonations and their correlation with an absolute time scale (Berggren, 1972) allow rough estimates to be made of the rates of sediment accumulation and also allow correlation of sediment type with these unchanging rates. In addition, the presence of certain nannoplankton (Bukry and others, 1971) can be used to infer nearshore marinebasin conditions, as opposed to an open-ocean environment, remote from land.

\section{RATE OF SEDIMENT ACCUMULATION}

Collation of Foraminifera and calcareous nannoplankton zones (Berggren, 1972) has permitted estimates of the accumulation rates where the zones are well delineated in the core. Readjusting of the age boundaries, utilizing $\mathrm{K}-\mathrm{Ar}$ dates of authigenic minerals, allows one to refine the estimates within narrower and narrower limits. The accuracy of the rate of sediment accumulation depends on (1) the accuracy of the radiogenic date and (2) the accuracy with which the fossil zone is defined. The new data compiled by Berggren (1972, fig. 2) show a range of plus or minus 5-10 percent in the radiogenic dates. The definition of zones utilized here depends on the investigators' sampling interval in holes 3,4 , and 6 . Where the sampling interval was given, it ranged from a fraction of a metre to slightly more than $20 \mathrm{~m}$. The percent change caused by this sampling factor on the accumulation rate is given in table 2 and is usually in a range similar to the error in the radiogenic age estimate.

The rate of sediment accumulation (table 2) tends to be higher closer to shore (hole 5) and higher in the oldest sediments cored (Paleocene, hole 4). A comparison of the rate of sediment accumulation on the Florida-Hatteras Slope with that on the inner Blake Plateau for the early Oligocene (holes 5 and 6) shows that sediment accumulated approximately eight times as fast on the slope.

Values are mainly less than $15 \mathrm{~mm} / 1,000$ years during the Eocene and Oligocene, and drop to 1-2 $\mathrm{mm} / 1,000$ years near the Eocene-Oligocene and Oligocene-Miocene boundaries. Bramlette and Wilcoxon (1967) pointed out the coincidence of a wellsorted calcarenitic sand with a 20-foot section that contains five nannofossil zones. Obviously this interval was subjected to much current activity during which much fine biogenic debris was swept by, and only the coarser tests accumulated at an extremely slow rate. However, this occurrence is the only clear example where limited sedimentation (as indicated by the presence of many faunal zones) matched sediment type that might be expected under such a circumstance. Most of the low estimates of sediment accumulation are marked by ooze or limestone. Even the ooze apparently was winnowed during its accumulation. Roth $(1970$, p. 814$)$ noted that only larger nannofossils characterized the section of ooze (Oligocene) in hole 6 so that the small index forms that delineate zones in the lower Oligocene are hard to find.

The rates of sediment accumulation for the North Atlantic reveal wide temporal and areal variation (Emery and Uchupi, 1972; Ericson and others, 1961). Accumulation rates (mainly terrigenous debris) average $30 \mathrm{~cm} / 1,000$ years on the Continental Slope during the Holocene and $5 \mathrm{~cm} / 1,000$ years on the deep-sea floor (Emery and Uchupi, 1972). Ericson and others (1961) found an average accumulation rate of $8.8 \mathrm{~cm} / 1,000$ years in 108 deep-sea cores they examined in the Atlantic and Caribbean, though their values range from 1.4 to $63.6 \mathrm{~cm} / 1,000$ years. 
STRATIGRAPHY AND TERTIARY DEVELOPMENT EAST OF FLORIDA

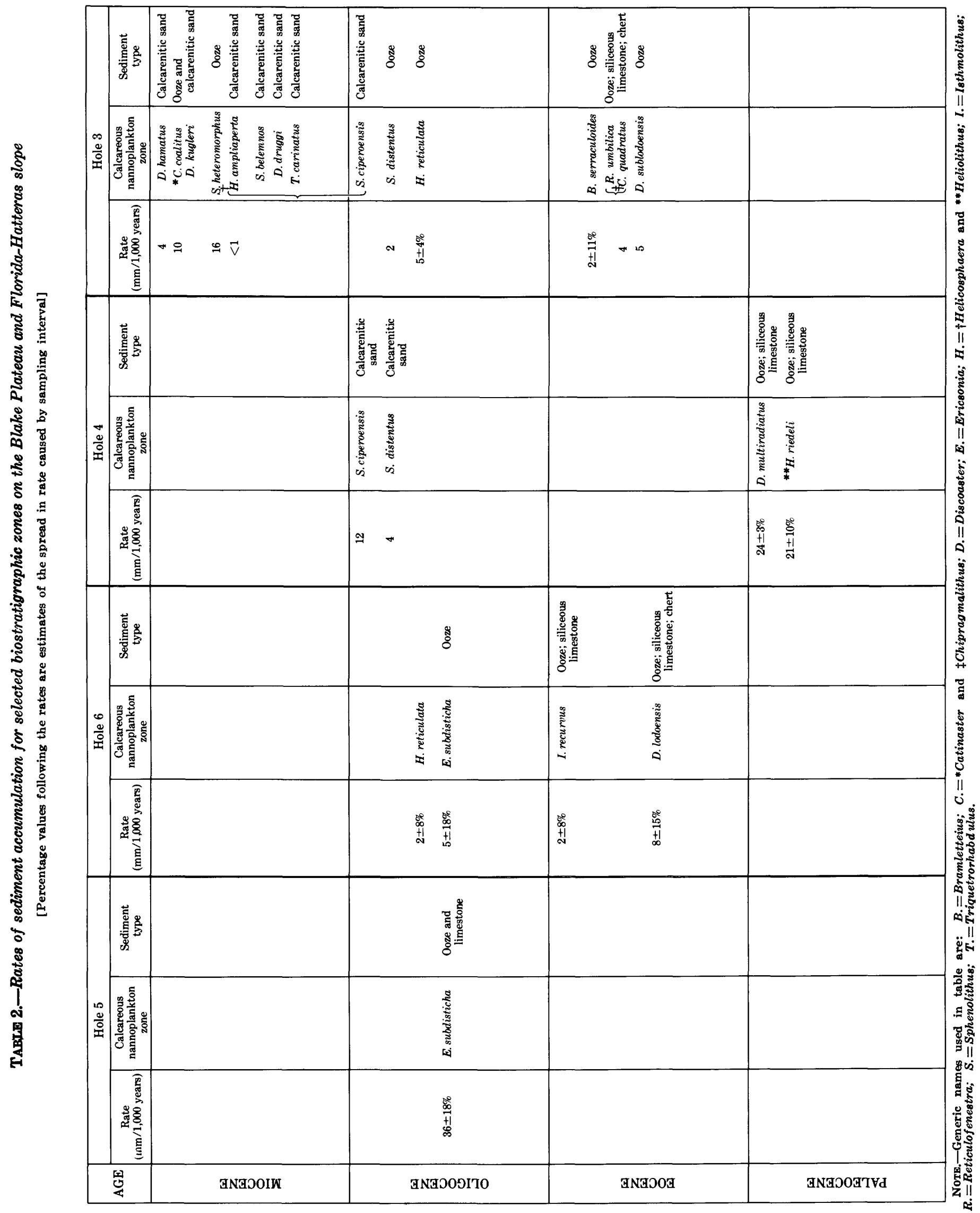


TABLE 3.-List of calcareous nannoplankton indicative of nearshore shelf or basin milieu

\begin{tabular}{|c|c|c|c|c|}
\hline Age & Hole 5 & Hole 6 & Hole 3 & Hole 4 \\
\hline Oligocene & $\begin{array}{l}\text { Braarudosphaera bigelowi } \\
\text { Braarudosphaera rosa } \\
\text { Lanthernithus minutus } \\
\text { Rhabdosphaera tenuis } \\
\text { Rhabdosphaera vitrea } \\
\text { Transversipuntis zigzag } \\
\text { Zygrhablithus bijugatus }\end{array}$ & $\begin{array}{l}\text { T. zigzag } \\
\text { Z. bijugatus }\end{array}$ & & \\
\hline Eocene & $\begin{array}{l}\text { Braarudosphaera bigelowi } \\
\text { Lanthernithus minutus }\end{array}$ & $\begin{array}{l}\text { Cyclococcolithina reticulata } \\
\text { Discolithina ocellata } \\
\text { D. pectinata } \\
\text { Hayella situliformis } \\
\text { Helicopontosphaera } \\
\text { seminulum seminulum } \\
\text { Lanternithus minutus } \\
\text { Lithostromation perdurum } \\
\text { Markalius inversus } \\
\text { Micrantholithus vesper } \\
\text { Pemma papillatum } \\
\text { Peritrachelina joidesa } \\
\text { Rhabdosphaera prolonga } \\
\text { R. tenuis } \\
\text { R. spinula } \\
\text { R. truncata } \\
\text { Syracosphaera labrosa } \\
\text { Transversopontis exilis } \\
\text { T. zigzag } \\
\text { Zygrhablithus bijugatus } \\
\text { bijugatus }\end{array}$ & $\begin{array}{l}\text { Cyclococcolithina reticulata } \\
\text { Hayella situliformis } \\
\text { Helicopontosphaera semi- } \\
\quad \text { nulum seminulum } \\
\text { Lanternithus minutus } \\
\text { Markalius inversus } \\
\text { Micrantholithus basquensis } \\
\text { M. crenulatus } \\
\text { M. procerus } \\
\text { M. vesper } \\
\text { Pemma papillatum } \\
\text { Peritrachelina joidesa } \\
\text { Zygrhablithus bijugatus } \\
\text { bijugatus }\end{array}$ & \\
\hline Paleocene & & & & $\begin{array}{l}\text { Fasciculithus schaubi } \\
\text { Zygrhablithus bijugatus }\end{array}$ \\
\hline
\end{tabular}

Pleistocene-Holocene estimates of carbonate deepsea sedimentation from the equatorial and North Atlantic made by Broecker (1971) showed values of about $2 \mathrm{~cm} / 1,000$ years. Deep-sea carbonate-accumulation rates of Pliocene sediments for Deep Sea Drilling Project (DSDP) legs $1,2,19$, and 11 range from $0.3 \mathrm{~cm} / 1,000$ years to $3.9 \mathrm{~cm} / 1,000$ years, with an average of $1.5 \mathrm{~cm} / 1,000$ years.

Though some of these preceding accumulation rates are approximate, they are not too much larger than those in table 2; the difference may reflect, in part, a bypassing of sediment over the Blake Plateau during the Tertiary-a bypassing that has varied with time.

Where fossil zonation is well delineated between holes, one episode of volcanism can be closely fixed in time. Ash occurs in the Spenolithis predistentus zone (Bramlette and Wilcoxon, 1967) of holes 3 and 4 , indicating a widespread dispersal of volcanic debris from an unknown volcanic center during the early Oligocene. Other occurrences of ash are dated, but they do not appear to be synchronous among holes 3,4 , and 6 , in part because of hiatuses present in one section but not in another.

\section{PALEOECOLOGY}

In the cores from the four holes $(3,4,5$, and 6$)$ examined for calcareous nannoplankton, three
5,6 ) contained a substantial number of forms (table 3) indicative of nearshore basin or shelf conditions (Bukry and others, 1971). Faunal lists given by Bramlette and Wilcoxon (1967), Roth (1970), Gartner (1971) and Roth and Hay (1967) contain some of the forms listed by Bukry, Douglas, Kling, and Krasheninnikov (1971) as indicative of nearshore conditions. Pelagic debris apparently accumulated on an ancient slope and plateau close enough to the coast that during the Eocene and Oligocene, many species indigenous to the nearshore area were carried offshore and mixed with open-ocean forms. A diminished planktonic-benthonic Foraminifera ratio (W. A. Berggren, oral commun., March 1974) also suggests a proximity to land, even though the water probably was beyond shelf depths.

Dr. R. C. Tjalsma (Woods Hole Oceanographic Institution, written commun. August 1974) examined the benthonic Foraminifera from the Paleocene of hole 4 (Blake Plateau, $98 \mathrm{~m}$ below the sea floor). The plankton-benthos ratio is high (90-95 percent planktonic forms); among the benthonic forms, lagenids (nodosariids and lenticolinids) dominate. He identified the following species:

Gaudyrina pyramidata Cushman G. laevigata Franke

Spiroplectammina excolata (Cushman)

Tritaxia globulifera (ten Dam and Sigal)

Dorothia ef. bulletta (Carsey) 
Siphonodosaria cf. abyssorum (Brady)

Astacolus jarvisi (Cushman)

Coryphostoma limonense? (Cushman)

Bulimina midwayensis Cushman and Parker

Tappanina selmensis (Cushman)

Pullenia minuta? Cushman

Gyroidinoides aequilateralis (Plummer)

Gavelinella beccariiformis (White)

Nuttallides truempyi (Nuttall)

Osangularia midwayana (Cushman and Todd)

From his examination he found a lack of species confined to the shelf environment and to lower bathyal-abyssal depths (greater than 1,000 m); deeper water species of Aragonia, Bulimina, Pullenia, Gavelinella, and Osangularia are absent. ${ }^{2}$ The faunal dominance of the lageniids and the low abundance of the general Gavelinella, Nuttallides, Bulimina, and Pullenia suggest an upper-middle bathyal depth (200-1,000 m) zonation for the sample.

These studies suggest that the Blake Plateau was at a depth similar to that at present. Beyond this, a more exact zonation is not possible.

\section{TECTONIC SETTING AND GEOLOGIC HISTORY}

The broad outlines of bathymetry for the margin were set largely before the beginning of the Tertiary, and the units penetrated in the six holes show the interplay of sedimentation and erosion since at least the early Tertiary. In all areas except the Blake Plateau, sedimentation during the Cretaceous and Tertiary kept up with regional subsidence, burying the major structural basins and arches that floor the area.

In some respects, the margin is a composite tectonically of the area to the north and the Bahamas to the south. To the south are thick platform deposits of Cretaceous and Tertiary carbonate sediments (Goodell and Garman, 1969) in a series of broad tectonic warps; reefs are built on inferred basement highs. The Blake Plateau is built over a broad trough, which, however, is not as wide or as extensive as the Bahama Platform. To the north, the main locus of sediment accumulation shifted seaward under the Blake Outer Ridge. Emery and Uchupi (1972) speculated that the northern end of the Blake Plateau trough may be cut by a northwesttrending fault which intersects coastal Georgia and may be an ancient oceanic fracture zone. Farther north, troughs such as the Baltimore Canyon trough and the Georges Bank basin are contained mainly within the Continental Shelf, where sedimentation during the Late Cretaceous and Tertiary appears to have prograded the shelf seaward and to have given

\footnotetext{
2 As are any representatives of Aragonia.
}

rise to a thicker accumulation of sediment concentrated over narrower troughs than to the south.

The main structural feature that the drilling confirmed is a dip reversal (fig. 8) of rocks at least as old as late Eocene. The reversal shows up in hole 1, where the top of the Ocala Limestone is found 133 $\mathrm{m}$ below sea level, whereas the same horizon is $\mathbf{1 5 4}$ $\mathrm{m}$ below sea level at Fernandina Beach, $43 \mathrm{~km}$ west. This small reversal supports the inference of Hersey, Bunce, Wyrick, and Dietz (1959, fig. 5), who show deeper horizons warped upward beneath the inner shelf off Jacksonville; between holes 1 and 2 , the average slope for the top of the Eocene is 1.1 $\mathrm{m} / \mathrm{km}$. Whether the warp is a major feature extending to the basement is open to question. Emery and Uchupi (1972, figs. 171 and 187) showed it as such a feature-a south-trending ridge, dying out to the south. Sheridan and others (1966) and Maher (1971) showed only a seaward-deepening basement, whereas Meyer and Woollard (1956) inferred a small southwest-trending basement ridge (Yamacraw Ridge) parallel to the Georgia coast and inshore a few kilometres. Antoine and Henry (1965, figs. 11 and 12) inferred a small south-trending flexure in a structure-contour map on the top of the lower Eocene, immediately off the Georgia coast. However, they did not extend the flexure down to pre-Cretaceous basement.

The changes in the thickness and lithology in the Cenozoic section from onshore to offshore (pl. 1) indicate periodic tectonic activity coupled with changes in the environment of deposition in a seaward direction. The main structural features of the Southeast Georgia embayment, Peninsular arch, and Blake Plateau trough came into existence during the Mesozoic or perhaps earlier (Sheridan and others, 1966; Chen, 1965), as indicated by thickness trends of formations on land (Maher, 1971) and reflectors offshore (Sheridan and others, 1966). Most of the change in thickness along the coast (Maher, 1971) is in the Cretaceous System; these changes in thickness help outline the major structural elements of the Peninsula arch, the Southeast Georgia embayment, and the Cape Fear arch.

For projection of the geologic history offshore, inferences from onshore stratigraphic studies provide a tie to the paleogeography of the region, the environments of deposition, and the active tectonic elements. In Florida, Chen (1965) found that the Peninsular arch is well outlined by thinning of the Eocene Series over the feature and the parallelism in strike of the isopachs and facies adjacent to the arch. The Suwanee Channel marked a major facies 
rate approaching $36 \mathrm{~mm} / 1,000$ years (see section on Paleontology) through seaward progradation on the Florida-Hatteras Slope. Because the sea level was lower, one might surmise that well-sorted currentwinnowed carbonate sand ought to have accumulated on the platform. Yet, unlike that in the Eocene rocks, the lithologic change in Oligocene rocks from shelf holes to the slope is not toward more and more finegrained carbonate. Poorly sorted calcareous oozes and carbonate mudstones are logged in both areas and seem to indicate that the calcareous mud accumulated in sheltered areas on the platform, possibly in the lee of islands or banks.

Beneath the Blake Plateau, calcareous ooze of Oligocene age (holes 3 and 6) is interbedded with thin ash layers; studies by Blow (1969) showed that all the Foraminiferal zones that he distinguished are present in hole 3; Bramlette and Wilcoxon (1967) found much the same for the calcareous nannofossils from the same hole. The completeness of the section indicates a fairly continuous record of sedimentation, though at a slow rate of $5 \mathrm{~mm} / 1,000$ years or less, particularly during the late Oligocene (table 2 ).

At hole 4, a slightly less complete fossil record (Blow, 1969; Bramlette and Wilcoxon, 1967) still shows an accumulation rate similar to that in hole 3 ; the prevalence of calcarenitic sand probably indicates that this part of the Blake Plateau was more heavily reworked by bottom currents. At hole 6 , the completeness of the Oligocene section is not known, and, though an ooze, the lower part does show evidence of reworking (Roth, 1970, p. 814) as indicated by the presence of only large nannofossils.

The closing of the Suwannee Channel (Chen, 1965) contributed a profound change in the type of sediments deposited during the Miocene. As described by Goodell and Yon (1960) for northeast Florida, the strata of Miocene and younger age thicken to more than 500 feet $(152 \mathrm{~m})$ and are mainly phosphatic clays. The thickened sequence continues on into the Southeast Georgia embayment, which acted as a depocenter for the southwardspreading clastic materials. Toward the south edge of the embayment, green phosphatic sandy clay interfingers with phosphatic and calcareous shelf sands. To the west, along the Georgia-Florida line, the clay and sand interfinger with sandy dolomitea unit that becomes extensive in the panhandle of Florida. Goodell and Yon (1960) noted that the Peninsular and Chattahoochee arches acted as partial barriers to the influx of clastic debris. As can be seen from plate 1 , the Miocene Series eventually thins to the north and becomes limy.
From thickness and lithology trends, the Miocene Series is assumed to have accumulated in a partially restricted Gulf of Mexico encompassed on three sides by carbonate banks. The area of northeastern Florida and southeastern Georgia was a depocenter that probably changed from an open marine shelf in the early Miocene (limestone in the lowest parts of the thick section) to an embayment having a partly restricted circulation in the middle and late Miocene; this area was marked by the influx of fine clastic materials-some as airborne volcanic ash (Hathaway and others, 1970). Goodell and Yon (1960) suggested that the intercalated sands are time-transgressive units that migrated into the embayment from the north.

The conditions under which the phosphatic clay accumulated are not well understood. Several features comment on the milieu, but they do not define it. The phosphatic silty clay is not well stratified; indeed the wispy bedding and scattered biogenic debris are suggestive of periodic reworking by epibenthic fauna. The almost complete lack of planktonic Foraminifera and calcareous nannoplankton in the onshore equivalent (Hawthorn Formation) of the silty clay (Akers 1972, p. 9) makes me wonder how much access the bay (s) had to the open ocean. In holes 1 and 2, Saito (Bunce and others, 1965) was able to find several layers of diatoms and radiolarians but hardly any planktonic Foraminifera.

The accumulation of phosphorite pebbles in distinct horizons indicates some transportation and concentration. The subrounded nature of the pebbles and their internal structure lend support to the idea of limited transport prior to burial. How the sporbo originated initially is also not well understood. Were they phosphatized fecal pellets or did they originate as discrete nuclei of inorganic phosphate growth in the sediment? Some of the pebbles are obviously phosphatized sediment, because they show a finegrained clastic internal texture of scattered quartz and carbonate (rare) grains, opaque inclusions, and collophane; dark rims that border some pebbles and the sporbo, indicate some concentration of impurities during growth.

The gamma-ray logs (pls. 1 and 2) suggest that most of the phosphate is concentrated in sediment of early Miocene age, that some phosphatic zones are widespread, and that the phosphatic zones are more prevalent in the thicker sections of the Miocene. One of the main zones of phosphate-rich sediment ( $p l$. 1) is marked by a distinctive correlative pattern in the gamma-ray log, stretching approximately 100 $\mathrm{km}$ from hole 2 on the shelf to at least the Fer- 
nandina Beach well. Though the lithology changes between the holes, the amount of phosphate appears constant and seems to suggest fairly uniform conditions over a wide area. Further, the zones appear to extend through more of the Miocene section, though the upper part of the section still is not as phosphatic as the lower part, judging by the logs.

These relations (partial correlation of gamma ray logs, poor correlation of borehole lithology) indicate that the milieu in which the phosphate was formed and transported covered a wide area veneered by many different types of bottom sediment, and that the present inshore area was affected over more of the Miocene shelf than the present shelf. The widespread phosphatization, the lateral changes in sediment type, and the restricted fauna appear to typify a restricted shallow bay or gulf that opened onto the shelf. Situated between carbonate banks to the south and a subdued landmass to the north, the gulf probably had an irregular floor-one in which bottom currents reworked and sorted the debris into tabular sands and zones of phosphatic pebbles. More phosphate zones under Georgia, where subsidence was greater, and the presence of some interbedded dolomitic limestones may indicate that coastal lagoons bordered the restricted gulf.

Calcareous ooze continued to accumulate at widely differing rates during the Miocene (table 2). At hole 3 , bottom currents reworked bioclastic debris in the area during a part of the early Miocene so that calcareous ooze accumulated at one-tenth the rate of the fine calcareous ooze that followed it. Much of the Miocene section is calcarenitic sand in holes 4 and 3, pointing to the efficacy of the bottom currents in sorting and winnowing the calcareous debris. The increasing amount of calcarenitic sand and the lack of ash beds at a time when they are thought to have had a significant contribution to the shelf and Coastal Plain (Hathaway and others, 1970, p. E22) also strongly indicates that the Blake Plateau was being more heavily reworked by bottom currents, perhaps part of the ancestral Gulf Stream. Certainly by the late Tertiary, the sorting of biogenic debris and the pronounced post-Oligocene-Miocene unconformity in all three holes on the Blake Plateau indicate that the area was a zone of active scour and sediment transport.

Post-Miocene time was marked by diminished sedimentation of coarse sediment on the shelf and a relatively thick accumulation of sediment on the Florida-Hatteras Slope; deposition was preceded by removal of Miocene strata on the slope and inner Blake Plateau. The thinness of the shelf section, the incorporation of detritus (phosphate and glauconite) from Miocene and older strata, and the presence of a coarse terrigenous sediment (mainly as fine to medium quartzose sand) point to widespread marine and nonmarine reworking of the shelf sediments. In response to Quaternary glaciation, the shelves were exposed, and rivers periodically introduced some coarse detritus to the area. Widespread marine reworking of the debris is indicated by shallow marine fauna of benthonic Foraminifera, broken pelecypod shells, coral, and gastropods found in both shelf holes, and by the superficial oolites in hole 2.

As in the Oligocene, the main loci of deposition was the upper Hatteras-Florida Slope where a broad apron of winnowed calcareous sand mixed with terrigenous silt accumulated. An abundant fauna of planktonic Foraminifera and biogenic debris (Charm and others, 1969) containing lesser amounts of siliceous sponge spicules and echinoid debris supports the idea that the present upper Florida-Hatteras Slope was also a slope in the past, receiving a rain of pelagic skeletal debris and the influx of some fine terrigenous debris, particularly during lowered stands of sea level in the Pleistocene. Some winnowing by bottom currents is indicated by the good sorting of some of the calcarenitic sands and the clastic detritus derived from older units.

The picture that emerges from the study of the stratigraphy off northeastern Florida (fig. 9) is of a carbonate platform periodically emergent during the Tertiary and of a slope and deep-water plateau on which carbonate ooze accumulated to the east. Gradual upbuilding of the shelf by shallow-water carbonate debris during the Eocene gave way to deposition of fine-grained deeper ooze on the flanks of the platform and on the Blake Plateau. The shelf was partly emergent during the Oligocene so that most of the fine-grained carbonate detritus accumulated on the Florida-Hatteras Slope. A thinner sequence of the same age accumulated on the Blake Plateau under conditions relatively free of bottom-current scour, judging by the thin ash layers intercalated with the calcareous ooze. Even here, and during the late Eocene and early Oligocene, the bottom was subjected to current scour, as indicated by the missing biostratigraphic zones. Current scour affected the Blake Plateau much more during the Miocene and post-Miocene, giving rise to a winnowed calcarenitic ooze of planktonic forms. On the shelf during the Miocene, increasing amounts of terrigenous silts and clays accumulated in a partly closed gulf or sound. Broad warping of the shelf occurred during the Mio- 


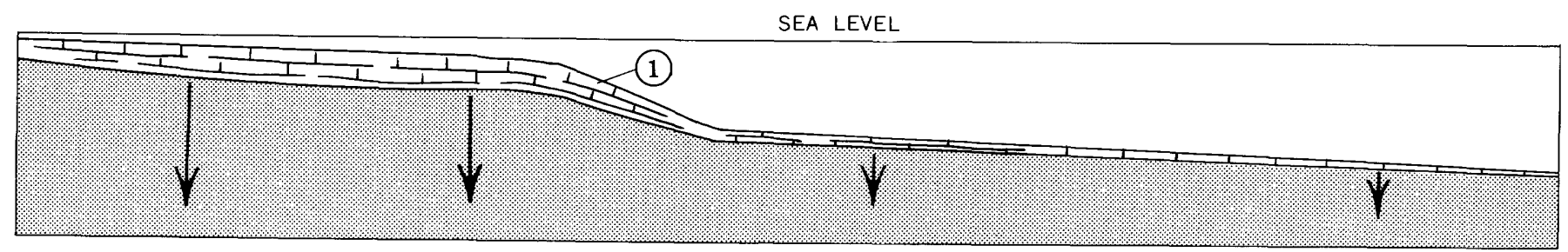

EOCENE

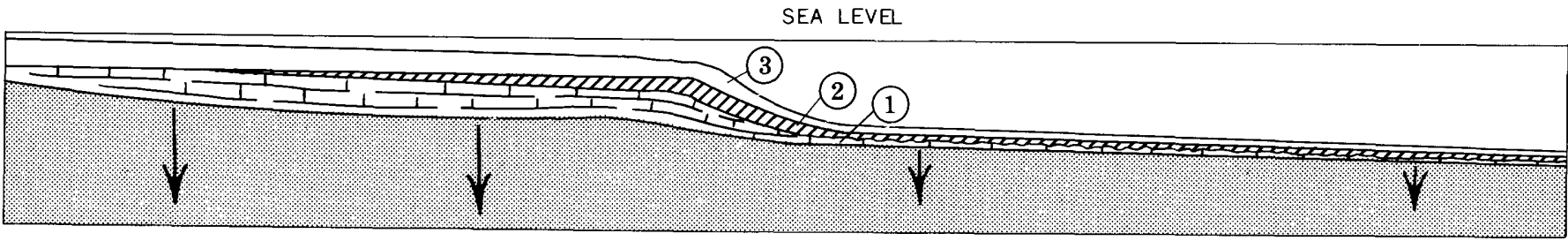

MIOCENE

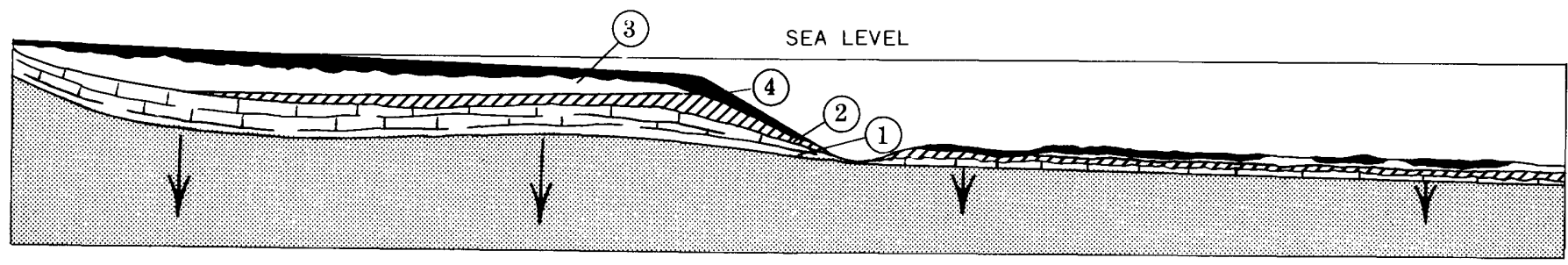

HOLOCENE

FIGURE 9.-Schematic diagrams showing development of the Florida margin during the Cenozoic. History is mainly one of the progradation and late warping of the shelf. Seaward of the shelf, sedimentation has been interrupted by nondeposition or erosion-shown by irregular contacts. Ages of deposits shown by numbers: 1, Eocene; 2, Oligocene; 3, Miocene; 4, Holocene. Arrows indicate amount of relative subsidence.

cene or later and was followed by wide eustatic shifts in sea level during the Quaternary and erosion of the Miocene Series on the upper Florida-Hatteras Slope.

\section{REFERENCES.CITED}

Akers, W. H., 1972, Planktonic foraminifera and biostratigraphy of some Neogene formations, northern Florida and Atlantic Coastal Plain: Tulane Studies Geology and Paleontology, v. 9, no. 1-4, 139 p.

Antoine, J. W., and Henry, V. J., Jr., 1965, Seismic refraction study of shallow part of continental shelf off Georgia coast: Am Assoc. Petroleum Geologists Bull., v. 49, no. 5, p. 601-609.

Berggren, W. A., 1972, A Cenozoic time-scale-some implications for regional geology and paleobiogeography: Lethaia v. 5, no. 2, p. 195-215.

Blow, W. H., 1969, Late Middle Eocene to Recent planktonic foraminiferal biostratigraphy: Internat. Conf. Planktonic Microfossils, 1st, Geneva, 1967, Proc., v. 1, p. 199-422.

Bramlette, M. N., and Wilcoxon, J. A., 1967, Middle Tertiary calcareous nannoplankton of the Cipero section, Trinidad, W. I.: Tulane Studies Geology and Paleontology, v. 5, no. 3, p. 93-131.
Broecker, W. S., 1971, Calcite accumulation rates and glacial to interglacial changes in oceanic mixing, in Turekian, K. K., ed., The late Cenozoic glacial ages: New Haven, Yale Univ. Press, p. 239-265.

Bukry, David, Douglas, R. G., Kling, S. A., and Krasheninnikov, V. V., 1971, Planktonic microfossil biostratigraphy of the northwestern Pacific area, in Fischer, A. G. and others, 1971, Initial Reports of the Deep Sea Drilling Project, v. 6: Washington, D.C., U.S. Govt. Printing Office, p. 1253-1300.

Bunce, E. T., Emery, K. O., Gerard, R. D., Knott, S. T., Lidz, Louis, Saito, Tsunemasa, and Schlee, John, 1965, Ocean drilling on the continental margin: Science, v. 150, no. 3697, p. 709-716.

Charm, W. B., Nesteroff, W. D., and Valdes, Sylvia, 1969, Detailed stratigraphic description of the JOIDES cores on the continental margin off Florida: U.S. Geol. Survey Prof. Paper 581-D, p. D1-D13.

Chen, C. S., 1965, The regional lithostratigraphic analysis of Paleocene and Eocene rocks of Florida: Florida Geol. Survey Bull. 45, $105 \mathrm{p}$.

Colquhoun, D. J., Heron, S. D., Jr., Johnson, H. S., Jr., Pooser, W. K., and Siple, G. E., 1969, Up-dip PaleoceneEocene stratigraphy of South Carolina reviewed: South Carolina Div. Geology Geol. Notes, v. 13, no. 1, p. 1-25 26a-261. 
Dunham, R., J., 1962, Classification of carbonate rocks according to depositional textures, in Ham, W. E., Classification of carbonate rocks-A symposium: Am. Assoc. Petroleum Geologists Mem. 1, p. 108-121.

Eardley, A. J., 1962, Structural gealogy of North America (2d. ed.) : New York, Harper and Row, 743 p.

Emery, K. O., and Uchupi, Elazar, 1972, Western North Atlantic Ocean: topography, rocks, structure, water, life, and sediments: Am. Assoc. Petroleum Geologists Mem. $17,532 \mathrm{p}$.

Emery, K. O., and Zarudzki, E. F. K., 1967, Seismic reflection profiles along the drill holes on the continental margin off Florida: U.S. Geol. Survey Prof. Paper 581-A, p. A1A8.

Ericson, D. B., Ewing, Maurice, and Heezen, B. C., 1952, Turbidity currents and sediments in North Atlantic: Am. Assoc. Petroleum Geologists Bull., v. 36, no. 3, p. 489-511.

Ericson, D. B., Ewing, Maurice, Wollin, Goesta, and Heezen, B. C., 1961, Atlantic deep-sea sediment cores: Geol. Soc. America Bull., v. 72, no. 2, p. 193-285.

Ewing, John, Ewing, Maurice, and Leyden, Robert, 1966, Seismic-profiler survey of Blake Plateau: Am. Assoc. Petroleum Geologists Bull., v. 50, no. 9, p. 1948-1971.

Gartner, Stefan, Jr., 1971, Calcareous nannofossils from the JOIDES Blake Plateau cores, and revision of Paleogene nannofossil zonation: Tulane Studies Geology and Paleontology, v. 8 , no. 3 , p. 101-121.

Goddard, E. N., chairman, and others, 1948, Rock color chart: Washington, D.C., Natl. Research Council, 6 p. (Repub. by Geol. Soc. America, 1951; reprinted 1963.)

Goodell, H. G., and Garman, R. K., 1969, Carbonate geochemistry of Superior deep test well, Andros Island, Bahamas: Am. Assoc. Petroleum Geologists Bull., v. 53, no. 3, p. 513-536.

Goodell, H. G., and Yon, J. W., Jr., 1960, The regional lithostratigraphy of the post-Eocene rocks of Florida, in Puri, H. S., Late Cenozoic stratigraphy and sedimentation of central Florida: Tallahassee, Fla., Southeastern Geol. Soc. Guidebook, 9th Field Trip, 1960, p. 75-113.

Hathaway, J. C., McFarlin, P. F., and Ross, D. A., 1970, Mineralogy and origin of sediments from drill holes on the continental margin off Florida: U.S. Geol. Survey Prof. Paper 581-E, p. E1-E26.

Heezen, B. C., and Sheridan, R. E., 1966, Lower Cretaceous rocks (Neocomian-Albian) dredged from Blake escarpment: Science, v. 154, no. 3757 p. 1644-1647.

Herrick, S. M., and Vorhis, R. C., 1963, Subsurface geology of the Georgia Coastal Plain: Georgia Geol. Survey Inf. Circ. 25, $78 \mathrm{p}$.

Hersey, J. B., Bunce, E. T., Wyrick, R. F., and Dietz, F. T., 1959, Geophysical investigation of the continental margin between Cape Henry, Virginia, and Jacksonville, Florida: Geol. Soc. American Bull., v. 70, no. 4, p. 437-466.

Leve, G. W., 1961, Preliminary investigation of the groundwater resources of northeast Florida: Florida Geol. Survey Inf. Circ. 27, 28 p.

McCollum, M. J., and Herrick, S. M., 1964, Offshore extension of the upper Eocene to Recent stratigraphic sequence in southeastern Georgia: U.S. Geol. Survey Prof. Paper 501-C, p. C61-C63.

Maher, J. C., 1971, Geologic framework and petroleum potential of the Atlantic Coastal Plain and Continental Shelf: U.S. Geol. Survey Prof. Paper 659, 98 p.

Meyer, R. P., and Woollard, G .P., 1956, Seismic evidence for basement uplift in the Georgia-South Carolina coastal plain [abs.]: Geol. Soc. America Bull., v. 67, no. 12, p. 1721.

Milliman, J. D., 1972, Atlantic Continental Shelf and Slope of the United States-Petrology of the sand fraction of sediments, northern New Jersey to southern Florida: U.S. Geol. Survey Prof. Paper 529-J, p. J1-J40.

Milliman, J. D., Manheim, F. T., Pratt, R. M., and Zarudzki, E. F. K., 1967, Alvin dives on the continental margin off the southeastern United States July 2-13, 1967: Woods Hole Oceanog. Inst. Tech. Rept. 67-80, 64 p.

Pratt, R. M., and Heezen, B. C., 1964, Topography of the Blake Plateau: Deep-Sea Research, v. 11, no. 5, p. 721728.

Rona, P. A., 1973, Relations between rates of sediment accumulation on continental shelves, sea-floor spreading, and eustacy inferred from the central North Atlantic: Geol. Soc. America Bull., v. 84, no. 9, p. 2851-2871.

Roth, P. H., 1970, Oligocene calcareous nannoplankton biostratigraphy: Eclogae Geol. Helvetiae, v. 63, no. 3, p. 799-881.

Roth, P. H., and Hay, W. W., 1967, Zonation of the Oligocene interval, in Hay, W. W. and others, 1967, Calcareous nannoplankton zonation of the Cenozoic of the Gulf Coast and Caribbean-Antillean area, and transoceanic correlation: Gulf Coast Assoc. Geol. Socs. Trans., v. 17, p. 439441.

Sheridan, R. E., Drake, C. L., Nafe, J. E., and Hennion, J., 1965, Seismic refraction measurements of the continental margin east of Florida [abs.]: Geol. Soc. America Spec. Paper 82, p. 183.

1966, Seismic-refraction study of continental margin east of Florida: Am. Assoc. Petroleum Geologists Bull., v. 50 , no. 9 , p. $1972-1991$.

Sheridan, R. E., Smith, J. D., and Gardner, J., 1969, Rock dredges from Blake escarpment near Great Abaco Canyon: Am. Assoc. Petroleum Geologists Bull., v. 53, no. 12, p. 2551-2558.

Stetson, T. R., Squires, D. F., and Pratt, R. M., 1962, Coral banks occurring in deep water on the Blake Plateau: Am. Mus. Novitates, no. 2114, 39 p.

Uchupi, Elazer, 1968, Atlantic Continental Shelf and Slope of the United States-Physiography: U.S. Geol. Survey Prof. Paper 529-C, p. C1-30.

- 1970, Atlantic Continental Shelf and Slope of the United States-Shallow structure: U.S. Geol. Survey Prof. Paper 529-I, p. I1-I44.

Uchupi, Elazar, and Emery, K. O., 1967, Structure of continental margin off Atlantic coast of United States: Am. Assoc. Petroleum Geologists Bull., v. 51, no. 2, p. 223-234.

Zarudzki, E. F. K., and Uchupi, Elazar, 1968, Organic reef alignments on the continental margin south of Cape Hatteras: Geol. Soc. America Bull., v. 79, no. 12, p. 18671870. 



\section{Drilling on the Continental Margin off Florida}

GE O L O I C A L S U R V E Y P R OFES IONAL PAPER 581

This volume was published

as separate chapters $A-F$

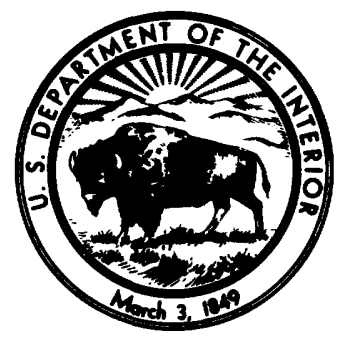


UNITED STATES DEPARTMENT OF THE INTERIOR

CECIL D. ANDRUS, Secretary

GEOLOGICAL SURVEY

V. E. McKelvey, Director 


\section{CONTENTS}

\section{[Letters designate the chapters]}

(A) Seismic reflection profiles along the drill holes on the continental margin off Florida, by K. O. Emery and E. F. K. Zarudzki.

(B) Calcium carbonate, organic carbon, and nitrogen in sediments from drill holes on the continental margin off Florida, by Jobst Hülsemann.

(C) Organic extracts from JOIDES cores off northeastern Florida, by E. E. Bray and E. D. Evans.

(D) Detailed stratigraphic description of the JOIDES cores on the continental margin off Florida, by W. B. Charm, W. D. Nesteroff, and Sylvia Valdes.

(E) Mineralogy and origin of sediments from drill holes on the continental margin off Florida, by John C. Hathaway, Peter F. McFarlin, and David A. Ross.

(F) Stratigraphy and Tertiary development of the continental margin east of Florida, by John Schlee. 